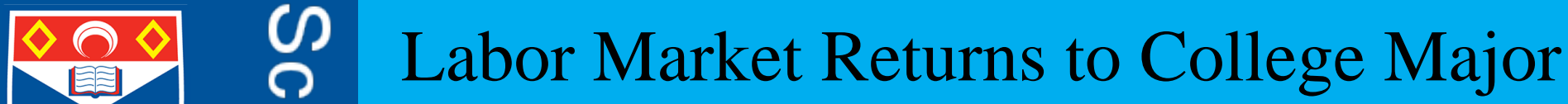 Specificity
}

University of St Andrews

Margaret Leighton and Jamin Speer

חᄁ

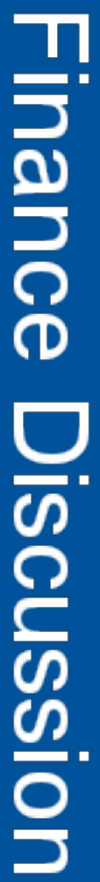

$\nabla$

(1)

0

(1)

के
School of Economics and Finance Discussion Paper No. 1709 16 May 2017 (revised 21 Dec 2017) JEL Classification: I26, J24, J31, I23

Keywords: human capital; general education; vocational education; higher education; specificity; specific human capital 


\title{
Labor Market Returns to College Major Specificity*
}

\author{
Margaret Leighton ${ }^{\dagger}$ and Jamin D. Speer ${ }^{\ddagger}$
}

December 21, 2017

\begin{abstract}
This paper defines and measures college major specificity and estimates its labor market return over a worker's life cycle. After reviewing other measures which have been used to measure specialization, we propose a novel approach grounded in human capital theory: a Gini coefficient based on the transferability of skills across occupations. We calculate and compare representative measures using data from the American Community Survey and the Baccalaureate and Beyond. We then use these measures to estimate the return to specialized higher education. Using our new measure, we find that the most "specific" majors clearly pay off the most over time. The initial annual earnings premium for the most specific majors is $8 \%$, all of which comes through wages and not hours worked. This premium declines with age but is positive at most ages. We then apply our measure to the question of entrepreneurs and managers. Despite enjoying higher average earnings, graduates from specific majors are 20-25\% less likely than average majors to become entrepreneurs or hold managerial positions, while the most general majors lead to the highest rates of entrepreneurship. This finding lends support to a prominent hypothesis from the literature on managers and entrepreneurs.
\end{abstract}

JEL codes I26 J24 J31 I23

${ }^{*}$ We thank Tugce Cuhadaroglu, Eric Eide, Bill Smith, and seminar participants at the University of St Andrews, Acadia University, Mount Allison University, University of Essex and the International Workshop on the Applied Economics of Education for helpful discussions. We gratefully acknowledge the National Center for Education Statistics for granting access to restricted longitudinal data.

$\dagger$ University of St Andrews: mal22@st-andrews.ac.uk

$\ddagger$ University of Memphis: jspeer@memphis.edu 


\title{
1 Introduction
}

\author{
If you're unsure, consider a "safe major". A safe major is a versatile major - \\ one that can translate into a variety of job opportunities. ${ }^{1}$ \\ Choose a major because it will prepare you for a specific career path or advanced \\ $s t u d y .^{2}$
}

The existence of large differences in earnings across graduates from different majors is now well established (see Carnevale et al. (2012); Lemieux (2014); Chevalier (2011); Walker and Zhu (2011), among many others), with recent advances demonstrating that the causal returns to certain majors are also substantial (Kirkebøen et al. (2016), Hastings et al. (2013)). Understanding what drives these differences is important. In order to do so, we need to define and study the characteristics that distinguish college majors.

This paper studies the level of specialization of college majors and estimates the return to specialized college degrees over the life cycle. College major specialization is of interest for two reasons. First, a large body of empirical and theoretical work has studied the role of specialized and general human capital on earnings, ${ }^{3}$ but insights from this literature have yet to be applied in a general way to fields of study in higher education. Second, the growing literature on the correspondence between education and occupation has important insights for understanding the return to college majors. ${ }^{4}$ The issue of specificity is relevant to any measure of horizontal mismatch: while it is intuitive that specialized workers can be damagingly mismatched, it is less clear that a similar correspondence can be defined for generally-skilled workers.

We first summarize the literature on college major specificity and recount the diverse ways in which specificity has been conceived and measured. Previous approaches have emphasized the occupational outcomes of the major, the diversity of the curriculum studied, or categorizations of majors as vocational or academic. These existing measures, while useful and meaningful in their own ways, have no strong basis in economic theory.

To correct this, we propose a novel measure of major specificity grounded in the notion

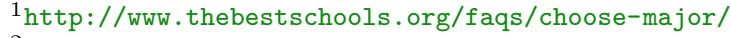

2 ww. princetonreview.com/college-advice/choosing-college-majors

${ }^{3}$ Initiated with the work of Becker (1962), human capital specificity has since been studied as occupation specific (e.g., Kambourov and Manovskii (2009)) task-specific (e.g., Gibbons and Waldman (2004)), firm-specific (e.g., Altonji and Shakotko (1987)), among others.

${ }^{4}$ See Sellami et al. (2016) for a review and discussion of existing approaches to measuring field-of-study mismatch; Liu et al. (2016) introduce a data-driven measure based on relative earnings.
} 
of specific and general human capital from the labor economics tradition (Becker (1962)). In this literature, the specificity of human capital is determined by its transferability - that is, how the value of skills changes when applied in different jobs. Our new measure, a modified Gini coefficient, captures this notion of transferability of skills across occupations for a given major. This measure of specificity behaves differently from existing measures, showing that some majors usually considered "specific" actually produce graduates with highly versatile skills (e.g., accounting), while other majors that are often thought of as "broad" actually produce skills that are quite specialized (e.g., economics).

We then apply our new measure to two sets of empirical questions. We first estimate the labor market returns to college major specificity. Using existing measures, there is typically a trade-off between early-career success and later-career success. "Vocational" majors, for example, enjoy a large initial earnings premium of about $15 \%$ over "academic" majors, but academic majors overtake vocational majors around age 35 and maintain the advantage through at least age 60 .

For our Gini measure, however, there is no such trade-off. Specific majors - those that provide specialized skills - earn the most at almost every age. General majors, which provide transferable skills, lag behind. This effect operates entirely through hourly wages and not through hours worked. Specialized majors do not necessarily provide more access to jobs, but they do provide access to better-paying jobs. For new graduates, the most specific majors earn $8 \%$ more annually than the average major (controlling for the ability and demographics of the graduates) and have $8 \%$ higher wages. By the time the worker is in his or her $40 \mathrm{~s}$ and $50 \mathrm{~s}$, this earnings advantage has fallen to $2-3 \%$.

Finally, we turn our attention to managers and entrepreneurs. A prominent literature suggests that those with more general human capital will be more likely to enter these types of jobs (e.g., Lazear (2005)). We find evidence in support of this hypothesis. Despite the advantage of specific majors in average earnings, these majors are associated with 20$25 \%$ lower probabilities of entrepreneurship and management occupations, when compared with average majors. By contrast, the most general majors are the most likely to lead to entrepreneurship. This lends support to the 'jack-of-all-trades' theory of entrepreneurs and also helps validate our measure of major specificity.

Recent literature on the returns to specialization in higher education has typically focused on countries with a well-defined vocational track. Looking across eleven European 
countries, Hanushek et al. (2017) find that vocational training improves employment outcomes for young people, but that generally educated individuals are more likely to be employed at older ages. Using Swedish registry data, Golsteyn and Stenberg (2017) find that vocational education is associated with an earnings premium early in the life cycle, but that this premium declines and is overtaken by general education in later years. Brunello and Rocco (2017) find that vocationally-trained workers in the UK have a persistent employment advantage with respect to generally-trained workers, although the magnitude of this advantage declines over the life cycle.

A smaller collection of papers has explored the return to specialization within fields. The most developed strand of this literature studies the return to skills breadth among entrepreneurs. ${ }^{5}$ Lazear (2005) introduces the hypothesis that entrepreneurs must be generalists, and finds evidence that both diverse occupational histories and broad educational backgrounds are associated with entrepreneurship. Much of the subsequent literature has focussed on role of diverse work histories (see, among others, Stuetzer et al. (2012), Wagner (2006), Silva (2007)), with little further evidence on the association between education breadth and entrepreneurial activity.

We make three main contributions to the literature. First, we develop a new theorydriven measure of college major specificity, showing that some majors typically thought of as general are actually specific in the skills they teach, and vice versa. We then apply our new measure to make two empirical contributions. In doing so, we show that our Gini measure is distinct from previous attempts to measure specificity, but also that it produces results consistent with predictions from other literatures. We provide the first estimates of the return to specific and general college majors, showing that specific majors typically earn the most. Finally, we show the first cross-major evidence in support of Lazear's (2005) jack-of-all-trades theory of entrepreneurship.

The remainder of the paper proceeds as follows. In Section 2, we review the measures that have been used, explicitly or implicitly, to capture the specialization of higher education degrees. In Section 3, we introduce our new measure, a Gini coefficient of income inequality, to proxy for the transferability of majors across occupations. In Section 4, we employ data from a range of sources to calculate college major specificity, using representative measures

\footnotetext{
${ }^{5}$ One exception is Artz et al. (2014), who compare the careers of agriculture majors who undertook more or less specialized curricula, and find that graduates with more specialized training have higher earnings in the agriculture industry, but that more broadly educated graduates do better in other occupations.
} 
from the families presented in Sections $2 \& 3$, while in Section 5 we estimate the wage and employment return to specificity. Section 6 concludes.

\section{Measuring Specialization}

\subsection{Curriculum-Based Measures}

One of the most direct methods for approximating the level of specialization of a college major is to look at the diversity of courses taken by graduates. Course-level information has been processed in a number of ways. A natural approach is to group subjects into categories, and to count the credits earned, or courses taken, in each category (see Silos and Smith (2015) for college credits and Tchuente (2016) for high school courses). Using data from the UK, Dolton and Vignoles (2002) and Malamud (2012) defined breadth of study at A-levels in a similar way. Detailed transcript data can further allow courses to be weighted by their credit hours and grade achieved (as in Rakitan and Artz (2015)).

Course diversity has been used in other ways to measure specialization as well. Lazear (2005) measures the "lopsidedness" of curricula taken by MBA students as the difference between the maximum number of courses a student has taken in any field and the average number of courses taken across all fields. Artz et al. (2014) use a modified version of this approach, taking the difference between credits inside the major and the largest number of credits earned from a department outside the major.

Without access to detailed transcript data, the timing of specialization offers a proxy measure of credit-specificity: early specializers spend a greater share of their education studying a single subject. Malamud (2010) compares early-specializing English university students to late-specializing Scots in this manner. In an early study on this topic, Morris (1973) classifies Ph.D. students as specialized if their bachelor's degree was in the same field as their doctoral studies.

Course-based measures put minimal restrictions on the number of field-of-study categories; however, many authors have found it practical to aggregate fields quite coarsely. Peri et al. (2015) restrict themselves to STEM versus non-STEM, while Kinsler and Pavan (2015) use science, business, and "other". Malamud (2010), in contrast, includes a range of classifications, with the narrowest including 42 majors.

The data requirements of the curriculum approach are formidable, requiring at a min- 
imum a representative sample of college transcripts for students in each major. This type of classification presents a deeper issue, however: it is not obvious that all college courses, or fields, are equally broad. Suppose the average education major takes $50 \%$ of his courses within the education department, while the average mathematics major takes $50 \%$ of her courses within the mathematics department. Does that imply that the two degrees are equally specialized? In terms of their course loads, perhaps they are; but if education courses are broader in scope than mathematics courses, then this measure could be quite misleading. It could be equally misleading if some skills are more widely useful than others. A journalism degree is very much focused on learning to write well - and thus might be classified as specific by a curriculum measure - but writing may be a skill which is valued in a wide range of occupations. It is not obvious, then, whether such a major should be thought of as general or specialized.

\subsection{Labor Market Orientation of Degree Program}

The notion that some fields of study are more closely linked to the labor market than others gives rise to a different family of measures of program specificity. The most widely used of these measures is the "vocational" versus "academic" dichotomy (see Hanushek et al. (2017), Brunello and Rocco (2017) and Golsteyn and Stenberg (2017), among many others). The classification of programs is most frequent in countries with established vocational education tracks and is typically based on the educational system's own classification, although recently Kreisman and Stange (2017) apply a similar approach to high school courses in the US.

Even within these two categories, though, some vocational programs are more specialized than others, as Coenen et al. (2015) explore in depth. In determining the breadth of different upper-secondary vocational programs in The Netherlands, the authors use graduates' assessments of whether their education program provides a better match to occupations within their domain, versus occupations outside it. Their measure classifies those programs for which their education prepares them equally well for both types of occupations as broad, while specialized education prepares students better for occupations within their domain. Parey (2016) compares the labor market returns to vocational education versus firm-based apprenticeship training - a type of education which is arguable even more specialized. He finds no earnings differences between the two, but that apprenticeships lead to an earlycareer employment advantage. 
In some cases, a classification of programs as vocational or general in one jurisdiction has been extended to others, as Stevens et al. (2015) do by linking California's community college Taxonomy of Programs to the national Classification of Instructional Programs. Other authors document changes within the vocational track, including a reform in Sweden that extended and expanded the general content of vocational secondary school Hall (2013).

Acknowledging that some academic programs have a stronger labor market orientation than others has led some authors to classify college majors as more or less vocational in nature. Saniter and Siedler (2014) classify majors as being labor market oriented if they lead to a particular profession. Bridet and Leighton (2015) employ a similar approach, using a highly restricted set of majors. Such classifications, which in theory may be related to the share of graduates from a certain major that ultimately work in a particular profession (see Section 2.3), are typically heavily reliant on perceived, rather than empirical, relation between majors and occupations.

\subsection{Measures Based on Eventual Occupation}

A third family of measures of specialization, increasingly popular in empirical studies, uses the distribution of graduates across occupations as a measure of specialization. Blom et al. (2015) compute major-specific measures of occupational concentration using a HirschmanHirfindahl Index (HHI). By this measure, majors which send most of their graduates to a small set of occupations are highly specialized, while those that send graduates evenly across many occupations are general. Using similar intuition, Altonji et al. (2012) calculate the share of graduates from each major who are employed in the three most popular occupations for that major.

This type of measure is perhaps the most intuitive measure of specialization, as people often think about majors based on what a student can do with that major after college. Students are regularly advised using this information as well, as the quotes at the beginning of the paper show, or are asked by their family and friends, "What are you going to do with that major?"

Still, an occupational measure does not tell us everything. Just because the skills of a major are typically applied in only a few occupations does not mean that they are not generally useful in any occupation. Engineering majors, for example, typically become engineers. However, it is possible that they would also make fine teachers, writers, and 
lawyers if they chose to do so. Thus, the skills possessed by graduates of a certain college major may be more or less generally applicable than an occupational measure will capture.

\section{A theory-driven measure of specialization}

While all of the existing measures of major specialization have their merits, none truly captures the notion of specificity as described in the tradition of labor economics. The concept of general and specific human capital originated with Becker (1962), who distinguished between human capital that is useful in any firm (general) and human capital that is useful in only one firm (specific). Examples of general human capital would be interpersonal skills, critical thinking, and problem solving, while specific skills might include the particular software used by the worker's firm (and not used by other firms), or an understanding of local systems and personnel.

Specificity need not be tied to the firm, however. Economists following Becker's lead have explored the ideas of industry-specific human capital (Neal (1995)), occupation-specific human capital (Kambourov and Manovskii (2009)), and task-specific human capital (Gibbons and Waldman (2004)). In all of these formulations, the difference between general and specific human capital is transferability. If human capital is general, it is useful across occupations, industries, or tasks. If human capital is specific, it is only useful within a given occupation, industry, or task.

The curriculum-based measures of specialization capture the variety of content studied in a major, the occupational measures capture the variety of outcomes, and the labor market orientation measures capture the clarity of the major's path to a particular type of job. While these all provide useful information, they do not specifically measure the transferability of skills described by Becker. For instance, a major may only teach a narrow set of skills, but if those skills are highly transferable, then the major should be counted as general rather than specific. Similarly, just because most of a major's graduates go to a small set of occupations does not mean that their skills are not valued in other occupations. The concept of vocational education is not designed to capture specificity either: engineering graduates, for instance, are known to attract high salaries across a wide range of different occupations.

Based on this idea, we propose a new measure of college major specificity based on 
the transferability of graduates' skills. We focus on occupations as the relevant unit of analysis, because occupations can be thought of as bundles of tasks, and literature has found occupation- and task-specific human capital to be powerful concepts (see, among many examples, Poletaev and Robinson (2008)). A general major, then, would be one whose graduates perform equally well across occupations - that is, their skills transfer in a similar manner to any occupation they choose. A specific major would be one whose graduates perform well in some occupations and poorly in others, so that their skills are not as transferable.

Another way to say this is that a general major is one in which the cost of "mismatch" is lower. In a specific major, the drop-off in productivity between a well-matched worker and a poorly-matched worker is large. In a general major, on the other hand, workers' skills are valued similarly across occupations so that the concept of mismatch is less clearly defined. The difference between being in the major's best occupation and worst occupation is small for general majors.

Consider the three hypothetical majors presented in Figure 1. Imagine that there are eleven occupations (as we will use in calculating our measure) and that we graph the earnings of each major's graduates in each occupation. Each point on the figure gives the ratio of the major's earnings in that occupation to the average earnings in the occupation. If the point is at 1 , the major is average in that occupation. If it is above 1 , the major is above average for that occupation, and below 1 means the major is below average for that occupation.

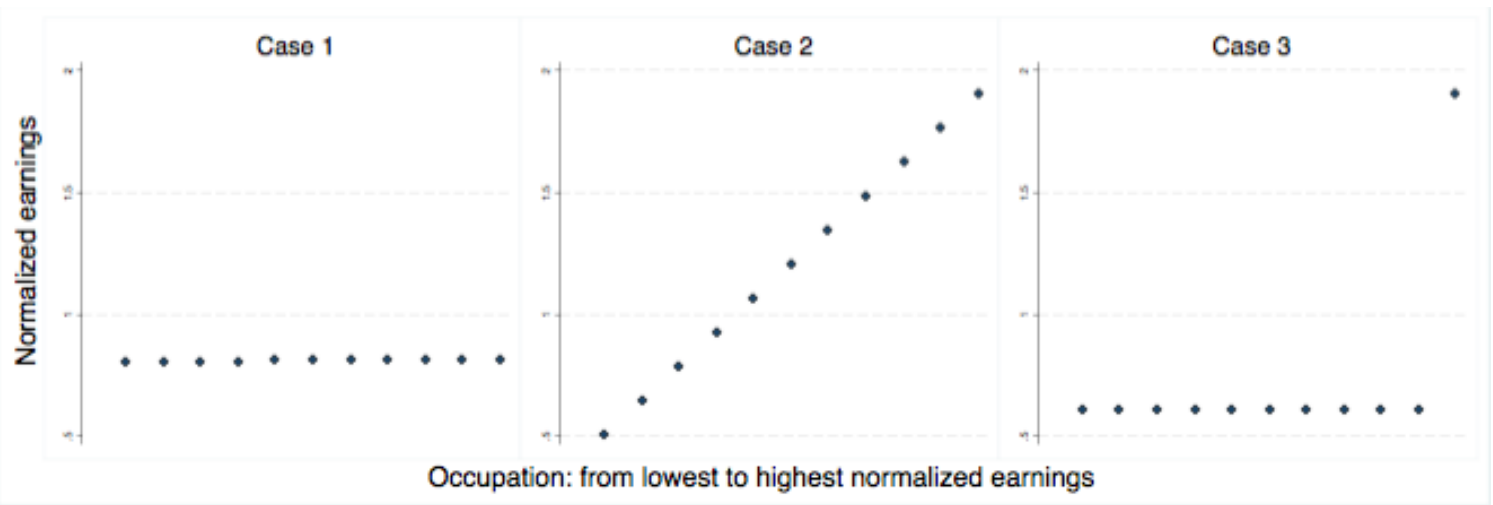

Figure 1: Distribution of earnings across occupations: hypothetical cases

The graph of hypothetical Case 1 (left panel) in the figure shows a flat line, meaning that this major's graduates perform similarly across occupations, relative to the average 
worker in those occupations. In this case, the major earns about $80 \%$ of the average in every occupation. We call this a general major. This can occur if the major's graduates are near the bottom of every occupation, near the middle of every occupation, or near the top of every occupation. A perfectly flat line would mean that the graduates perform exactly the same in every occupation, relative to the average person in that occupation. The flatter the line, the more general the major is.

On the other hand, consider Cases 2 and 3, which show two types of specific majors. Case 2's graduates are exceptional at one occupation (earning twice the average in that occupation), poor at another (earning half the average), and are "in-between" at everything else. Here, no matter what occupation the graduate is in and what occupation she switches to, the degree to which her skills are rewarded will change. In no two occupations is she equally productive. Thus, this is a much more specific major than Case 1.

In Case 3, the major's graduates are exceptional in one occupation and poor in every other occupation. This is clearly also a more specific major than Case 1, because if a graduate moved from the exceptional occupation to any other occupation, her skills would not transfer much at all. The cost of mismatch here is very high. Cases 2 and 3 are therefore two examples of specific majors. In each case, graduates can be found at the top and at the bottom of an occupation. For both, a good occupational match matters a great deal.

These hypothetical graphs show us that to measure major specificity based on the transferability of skills, what we want is a measure of inequality of earnings within a major across occupations. Case 1 shows an "equal" distribution of earnings across occupations. If this major were a country, and each occupation a person, it would show the lowest possible level of inequality. Cases 2 and 3 would be rated as more unequal. Thus, we look for a measure of inequality to capture our notion of major specificity. ${ }^{6}$

The large literature on measuring inequality provides guidance in selecting a measure suited to this task. ${ }^{7}$ The most common inequality measure, the Gini coefficient, has many of the properties we would wish for in our measure: mean independence (proportional

\footnotetext{
${ }^{6}$ Of course, the occupations that graduates go into are not random. The ideal way to measure skill transferability would be to randomly assign students to occupations. Absent this possibility, one could look at the change in wages for occupation switchers. However, switchers are a selected group; even if one found an exogenous reason for switching, the destination occupations would still be endogenous, and one would need switchers from every occupation to every other occupation to properly measure transferability. Given this, our approach is more practical and no less problematic than other approaches. We further address this question below by looking for evidence of selection across occupations.

${ }^{7}$ See Cowell (2000)'s chapter in the Handbook of Income Distribution for an excellent introductions to this body of work.
} 
increase in all incomes does not change the coefficient); symmetry (in our case, relative excellence in one occupation is equivalent to relative excellence in another); and population size independence (small and large majors can be accommodated). It also has the advantage of being a familiar and widely used measure.

When used to measure income inequality within a population, the Gini coefficient computes an average of the difference in incomes between each possible pair of individuals, normalized to always lie between 0 and 1 . In applying this method to inequality in earnings across occupations for graduates of a given major, we modify the measure in two important ways. First, instead of working with individual-level income, we compute the measure using the average income for each major-occupation cell. Second, we normalize incomes within each occupation by dividing by the average income for that occupation over majoroccupation cells. Neither of these modifications is innocuous: they are justified as follows.

We introduce the first modification to address the issue that graduates from each major are not distributed evenly across occupations. While we have observations in each of the 561 major-occupation cells in our data, in some majors, such as nursing, the vast majority of graduates work in a single occupation. We want our index to capture inequality in earnings across occupations, not within them, and therefore we take a single observation per major-occupation cell.

The second modification reflects our interest in measuring relative productivity differences across occupations. In our data, the average of earnings for education majors are almost exactly half that of the average for engineering majors, and the 90th percentile of education majors earns a similar amount to the 50th percentile of engineers. If a certain major produces excellent teachers and weak engineers, the raw earnings would suggest the major to be quite general. Normalizing earnings at the occupation level brings us closer to the intuition we wish to capture: a major which turns out workers at the top of one occupation but unremarkable in other jobs is quite specialized, while another major whose graduates perform relatively equally across occupations is general. ${ }^{8}$

We compute our measure using individuals early in their careers, restricting our data to those aged 25-35. We do this because we wish to focus on skills acquired during college, rather than those learned on-the-job, through further training, or through job-to-job transitions.

\footnotetext{
${ }^{8}$ When computing major-occupation mis-match, Liu et al. (2016) also use normalized wages, although their approach differs somewhat from ours.
} 
Now let us compare how the relative income distributions for actual majors in our dataset compares to the hypothetical cases in Figure 1. In Figure 2, we graph the occupationadjusted earnings in each occupation for six majors: environmental studies and other social sciences on the left, chemical engineering and economics in the middle, and finance and education \& library science on the right. ${ }^{9}$

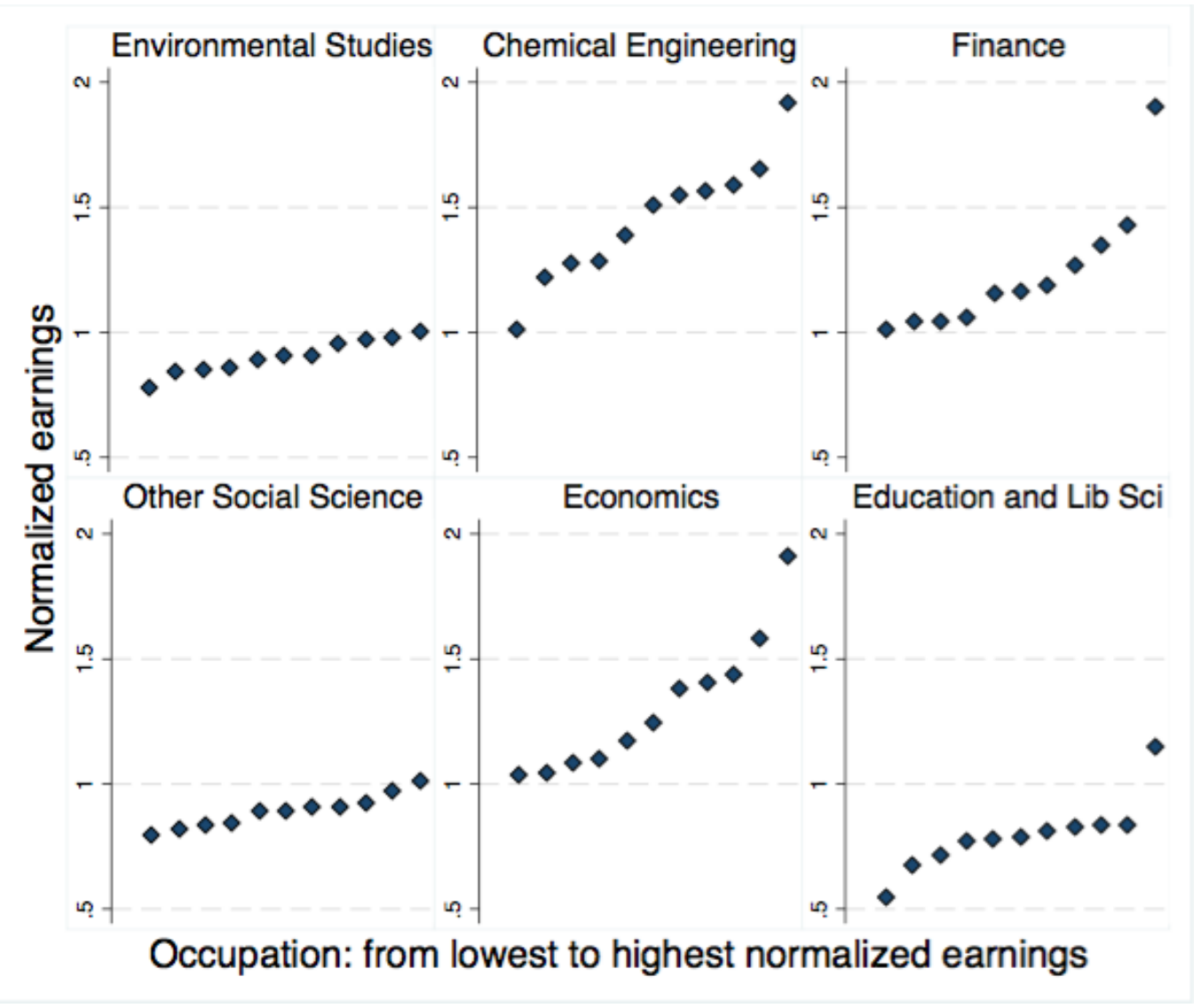

Figure 2: Distribution of earnings across occupations: examples of type cases

Environmental studies and other social sciences look much like Case 1 from Figure 1. The lines are relatively flat, showing that graduates of these majors perform similarly - relative to the average earnings in that occupation - in each occupation. In these cases, both majors are a bit below average in almost all occupations. Based on Figure 1, we argued that majors like this should be considered very general, as their skills are highly transferable across

\footnotetext{
${ }^{9}$ Secondary education is a separate major category, so the library science and education major does not include secondary education majors.
} 
occupations. As it turns out, environmental studies and other social sciences are the two most general majors as rated by the Gini coefficient.

Chemical engineering and economics look similar to hypothetical Case 2. They perform at a different level in each occupation - at the very top of one occupation and near the average in another, with the rest in between. These majors' skills appear to not be so transferable, as their value depends heavily on what occupation the graduate is working in.

The majors on the right, finance and education \& library science, look similar to Case 3. This is particularly true for education, where earnings are similar for most occupations - at around $70-80 \%$ of the occupation mean - but substantially higher in one occupation, which in this case is the education occupation. Finance features more of a general increase, but it too has a large spike in a single occupation. For these majors, mismatch is costly. If a worker is not in the best occupation, she will see her skills bring much less value.

All four of these majors - chemical engineering, economics, education \& library science, and finance - are among the ten most specific majors according to the Gini coefficient. Visual inspection of the data tells us that all of the most general majors show "flat" lines, while the most specific majors all resemble Cases 2 or 3 , or some combination of the two. ${ }^{10}$

A natural concern is that the diversity of earnings of graduates from a given major across occupations is driven by selection of graduates into those occupations based on ability. Earnings differences across occupations could simply be picking up this selection rather than our notion of skill transferability. It is undoubtedly true that there is selection on ability within a major across occupations. The question for us is whether there is differential selection across majors, causing us to call some "specific" and some "general" when in fact the difference between them is merely the degree of selection in those majors. In other words, if some majors have higher degrees of selection across occupations, then those majors will look specific to us, with large earnings differences across occupations. If other majors do not have as much selection, then they will appear general.

To explore this question, we calculate the average SAT scores for graduates of each major in the different occupations, and then compute the standard deviation of this measure within each major. The larger this standard deviation, the more selection seems to be occuring. We then look at the correlation between this standard deviation and our Gini coefficient to see if more specific majors according to the Gini have more selection. The correlation

\footnotetext{
${ }^{10} \mathrm{~A}$ list of the most specific and most general majors is found in Table 3.
} 
between these two measures is about 0.2 , and drops to 0 when major-occupation cells with sample sizes smaller than 3 are excluded from the SAT score calculation. ${ }^{11}$ The degree of selection across occupations for a major seems unrelated to its diversity of earnings. ${ }^{12}$ We are confident that our Gini coefficient is picking up real information about skill transferability and not merely selection.

A small number of papers conceptualize specificity in a similar way to our approach. Although specificity is not the focus of their paper, Borghans and Golsteyn (2007) directly estimate the transferability of skills between fields of study and fields of work. The authors rely on individuals who have "switched" fields, either within education or on the labor market. In the latter case, they rely on self-reported mismatch between education and occupation. Hartog and Vijverberg (2007), using occupations rather than education to define skill sets, estimate the mean and variance of wages in occupation cells defined by the reasoning, language, and math requirements given in the Dictionary of Occupation Titles (DOT). They find that combinations of language and math skills increase wage risk for college-educated men and women, when compared to having a high level of skill in either one.

Kinsler and Pavan (2015) and Coenen et al. (2015) address the issue of specificity explicitly, and therefore come closest to what we do here. Kinsler and Pavan (2015) estimate major specificity by comparing wages of students in related and unrelated occupations. Coenen et al. (2015) observe that an individual's productivity depends on the alignment of their skills with those required in their occupation. Both papers rely on self-reports by respondents on the link between their education and their work. Our goal here is to derive a measure of specialization that exploits the differential earnings of graduates from one major across a wide range of occupations, without relying on subjective assessments of the link between fields of study and fields of work.

\footnotetext{
${ }^{11}$ Information on SAT scores comes from the Baccalaureate and Beyond data, which has a much smaller sample size than the American Community Survey.

${ }^{12}$ As a further test, we plot cell-average SAT math scores overlaid on Figure 2: see Figure B.1 in the Appendix.
} 


\section{Empirical Comparison of Measures}

\subsection{Data}

We combine information from three data sets to estimate representative measures from the four families described in Sections 2 and 3. For measures requiring data on major, occupation, and earnings, we use the American Community Survey (ACS) from 2009 to 2015. To calculate the concentration of credits within the college curriculum, we use transcript data from the restricted version of the 1993/2003 Baccalaureate and Beyond (BB) dataset. We also use this dataset to generate statistics on the pre-college ability level of student entering different majors, measured as the major-level average and standard deviation of SAT scores.

For those measures which rely on labor market experiences, we use data from individuals aged 25 to 35 . Given that we are interested in proxying for the skills acquired in college, it is natural to focus on in the early part of their working lives. As a baseline, we use a set of 51 majors defined by the Baccalaureate and Beyond public-use data set (see Table A.1 in the Appendix). This is so we can compare our measures with other major-level characteristics from that data set, including the average SAT/ACT score.

\subsection{Definition of Measures}

\subsubsection{Occupation-based measure}

We use an occupational Hirschman-Herfindahl Index (HHI), as used by Blom et al. (2015), to measure the specificity of majors according to occupation. The HHI is calculated as follows:

$$
H H I_{m}=\sum_{o=1}^{N} s_{m o}^{2}
$$

where $m$ denotes the major, $o$ denotes each occupation, and $s_{m o}$ denotes the share of graduates from major $m$ that work in occupation $o$. This measure varies theoretically between 0 and 1, with higher values representing more specific majors - those whose graduates are concentrated in a small number of occupations. A value of 1 would represent a major for which all graduates enter a single occupation. We put the measure in standard deviations for ease of interpretation. 
To explore the robustness of this meausure, we have also calculated a "Top 5" measure, defined as the share of students from each major going to the five most common occupations for that major, similar to that used in Altonji et al. (2012). This is highly correlated with the HHI measure $(\rho>0.9)$ and behaves similarly in estimations.

\subsubsection{Curriculum-based measure}

We measure course specialization as the concentration of courses taken by graduates of that major, computing a Hirschman-Herfindahl Index of courses, as described above. In this case, the HHI is calculated as follows:

$$
H H I_{m}=\sum_{c=1}^{N} s_{m c}^{2}
$$

where $m$ denotes the major, $c$ denotes a coarse grouping of courses, ${ }^{13}$ and $s_{m c}$ denotes the average share of undergraduate credits (not courses) earned in field $c$ by students graduating from major $m$. This measure varies theoretically between 0 and 1 with higher values representing more specific majors - those whose graduates took most of their courses in a one or a few fields. A value of 1 would represent a major in which graduates took all their classes within one field. We put the measure in standard deviations for ease of interpretation. We construct this measure from the 1993/2003 Baccalaureate and Beyond restricted-use data.

In addition to the course HHI, we have experimented with two other measures. First, we have constructed an HHI based on all courses taken by a student, rather than the aggregated categories we use in our main measure. We first assign each and every course to a certain major and then calculate the HHI based on those classifications. Second, we have measured the share of total credits earned by a graduate that are from that graduate's own major. Surprisingly, these three measures are not highly correlated. The correlations between them are positive but range only from about 0.1 to 0.3 . Thus, unlike occupation-based measures, curriculum-based measures are highly dependent on which measure one chooses.

\subsubsection{Labor market orientation}

Although the United States does not have the pronounced vocational versus academic distinction present in many European countries, it is interesting to compare how other mea-

\footnotetext{
${ }^{13}$ For this measure we use relatively broad field categories: math, social science, business, foreign language, science and engineering, humanities, education, computer science, personal development, and other.
} 
Table 1: Vocational/Academic Categories

\begin{tabular}{ll}
\hline $\begin{array}{l}\text { Liberal Arts Education } \\
\text { (Academic, General) }\end{array}$ & $\begin{array}{l}\text { Career Technical Education } \\
\text { (Vocational, Specialized) }\end{array}$ \\
\hline Fine/performing arts & Agriculture and natural resources \\
Humanities & Business management \\
Interdisciplinary studies & Business support \\
Letters/English & Communications and design \\
Mathematics & Computer and information sciences \\
Science & Education \\
Social and behavioral sciences & Engineering, architecture and science technologies \\
& Health sciences \\
& Marketing \\
& Consumer services \\
& Protective services \\
& Public, legal, and social services \\
& Manufacturing, construction, repair, and transportation \\
\hline \hline
\end{tabular}

Source: top level categories abridged from NCES Postsecondary Taxonomy.

sures of specialization align with such a binary ordering. The National Center for Education Statistics (NCES) provides a classification of majors into academic (or liberal arts) and career (or career technical) education. ${ }^{14}$ We use this classification to code college majors as vocational or general. We interpret those majors classified as career technical education as vocational, i.e. specialized, while academic majors are interpreted as general. Table 1 presents the broad categories of majors according to this taxonomy.

\subsubsection{Skill transferability Gini measure}

Formally, our modified Gini coefficient is defined as follows:

$$
G_{m}=\frac{1}{2 n^{2} \mu_{m}} \sum_{j=1}^{o} \sum_{k=1}^{o}\left|y_{m j}-y_{m k}\right|
$$

where $n$ is the number of occupations, $y_{m j}$ and $y_{m k}$ are average incomes of graduates from major $m$ in occupations $j$ and $k, \mu_{m}$ is the average of these average incomes. We calculate the coefficient using data on majors, occupations and incomes of young workers (aged 25-35), aggregated at the major-occupation level: that is, we average incomes across individuals working in each major-occupation pair. These income observations are then normalized within occupation, by dividing each observation by the average across that occupation. Finally, we calculate our measure as the Gini coefficient applied to the resulting data, using

\footnotetext{
${ }^{14}$ This taxonomy can be found: https://nces.ed.gov/surveys/ctes/tables/postsec_tax.asp.
} 
the ginidesc command in Stata (Aliaga and Montoya (1999)).

\subsection{Comparing the Measures}

We proceed by comparing our four meausres in two ways: by exploring the correlation between the measures, and by visually inspecting the majors that are coded in the top and bottom ten of specificity according to each measure. ${ }^{15}$

Table 2 presents correlations between the measures, as well as correlations between each measure and three major-level test ability/skill measures: average SAT Math scores, average SAT verbal scores, and the standard deviation of SAT scores in the major. ${ }^{16}$ All four specificity measures are positively correlated, though some of the correlations are stronger than others. The Gini is most strongly correlated with the occupational HHI measure $(\rho=0.46)$. This means that majors with more easily transferable skills (low Gini) are more highly dispersed across occupations (low occupation HHI), and vice versa.

Interestingly, the Gini measure is only weakly correlated with the curriculum HHI measure. Because Gini measures the transferability of skills, one might have thought that it would be closely related to a measure that looks at course content (the skill inputs) directly. The weak relationship shows that just because a major requires only a narrow set of classes does not mean the skills taught by those classes are not widely applicable.

The other notable thing from Table 2 is the correlation between each measure and the average SAT scores in the major. Ideally, a specificity measure should be orthogonal to the ability of graduates from the major, as there is nothing about a major being "high-skill" or "low-skill" that should make it general or specific. Here, Gini is the least correlated of any measure with SAT scores. There is a slight positive correlation with SAT math scores $(\rho=0.095)$ and a slight negative correlation with SAT verbal scores $(\rho=-0.133)$. The other measures are more strongly correlated with SAT scores, particularly the vocational measure. Vocational majors are more likely to be low-SAT.

\footnotetext{
${ }^{15}$ For a full list of the majors' ranks on each measure, see Table A.1.

${ }^{16}$ These correlations are given with one observation per major - that is, with all majors weighted equally.
} 
Table 2: Correlations Between Major Specificity Measures

\begin{tabular}{|c|c|c|c|c|c|c|c|}
\hline Major measure: & Occ HHI & Curr HHI & Vocational & Gini & Avg SAT M & Avg SAT V & SAT St. Dev. \\
\hline Occ HHI & 1.000 & & & & & & \\
\hline Curr HHI & 0.211 & 1.000 & & & & & \\
\hline Vocational & 0.339 & 0.122 & 1.000 & & & & \\
\hline Gini & 0.460 & 0.120 & 0.226 & 1.000 & & & \\
\hline Avg SAT M & -0.137 & 0.200 & -0.189 & 0.095 & 1.000 & & \\
\hline Avg SAT V & -0.263 & 0.185 & -0.474 & -0.133 & 0.719 & 1.000 & \\
\hline SAT St Dev & -0.220 & -0.007 & -0.193 & 0.203 & -0.021 & 0.248 & 1.000 \\
\hline
\end{tabular}

We next inspect the most specific and most general majors, as ranked by our three continuous measures, in order to get a feel for where the correlations are coming from. Table 3 shows the top and bottom ten majors by each measure. The majors underlined are those that appear on the same list for all three measures. These are the majors that all three measures agree are very specific or very general. The majors listed in bold are those that are one of the ten most specific majors by one measure and one of the ten most general majors for another measure.

There is some broad agreement. Nursing is among the most specific majors by all three measures (ranking first for Gini and occupation HHI), while business is among the most general by all three measures. However, there is also much disagreement. Economics, for example, has one of the most general curricula but produces some of the most specialized, least transferable skills according to the Gini measure. Accounting, on the other hand, appears very specific by occupation HHI - meaning that a large fraction of accounting majors become accountants - but the Gini tells us that an accountant's skills are actually highly transferable. This makes sense if the accounting majors who do not become accountants do similarly well in those other occupations as those who become accountants do in theirs.

The Gini measure also shows that traditional categorizations of majors mask a great deal of variation in specialization. On average, STEM (science, technology, engineering, and mathematics) majors are somewhat specific (0.14 standard deviations above the mean major) by Gini, while arts, humanities, and social science (AHSS) majors are quite general (0.42 standard deviations below the mean major). However, STEM majors are scattered throughout the distribution of specificity. Two are in the top ten majors, two are in the bottom ten, and the rest are distributed almost uniformly. One can thus not say that STEM majors are specific or general; it depends entirely on the major one is talking about. Most social sciences are in the more general half of the distribution, with the notable exception 
of economics, which is among the most specific majors. Humanities majors are also mostly general, but foreign languages are an exception, ranked 20th out of 51 majors in specificity.

Clearly, whether a major is general or specific depends on the definition one uses and how that definition is implemented empirically. Is secondary education a specific major or a general major? The answer depends on if one means occupational dispersion (specific), transferability of skills (also specific), or the breadth of the curriculum (general). This table shows that our Gini measure, while bearing some relationship to the existing measures of specificity, captures something about majors that is not captured by these other measures.

Table 3: Majors in Top and Bottom Ten of Specificity

\begin{tabular}{|c|c|c|c|}
\hline Specificity measure: & Occupational HHI & Curriculum HHI & Gini \\
\hline Top ten & $\begin{array}{l}\text { Nursing } \\
\text { Education/Library Science } \\
\text { Secondary Education } \\
\text { Accounting } \\
\text { Commercial Art and Design } \\
\text { Civil Engineering } \\
\text { Medical Tech } \\
\text { Architecture } \\
\text { Social Work/Human Resources } \\
\text { Computer Programming }\end{array}$ & $\begin{array}{l}\text { Film and Other Arts } \\
\text { Chemical Engineering } \\
\text { Architecture } \\
\text { Civil Engineering } \\
\text { Nursing } \\
\text { Commercial Art and Design } \\
\text { Mechanical Engineering } \\
\text { Protective Services } \\
\text { Precision Production/Industrial Arts } \\
\text { Social Work/Human Resources }\end{array}$ & $\begin{array}{l}\text { Nursing } \\
\text { Computer Programming } \\
\text { Economics } \\
\text { Secondary Education } \\
\text { Finance } \\
\text { Medical Tech } \\
\text { Chemical Engineering } \\
\text { Family/Consumer Science } \\
\text { Education/Library Science } \\
\text { Other Med/Health Services }\end{array}$ \\
\hline Bottom ten & $\begin{array}{l}\text { Environmental Studies } \\
\text { Communications } \\
\text { Other Social Sciences } \\
\text { Misc. Business/Med Support } \\
\text { Public Health } \\
\text { General Science } \\
\text { Film and Other Arts } \\
\text { Agriculture } \\
\text { Business } \\
\text { Area Studies }\end{array}$ & $\begin{array}{l}\text { Mathematics } \\
\text { Secondary Education } \\
\text { Computer and Info Tech } \\
\text { Fitness and Nutrition } \\
\text { Misc. Business/Med Support } \\
\text { Computer Programming } \\
\text { General Science } \\
\text { Engineering Tech } \\
\text { Economics } \\
\text { Business }\end{array}$ & $\begin{array}{l}\text { Other Social Sciences } \\
\text { Environmental Studies } \\
\text { Misc. Business/Med Support } \\
\text { Mathematics } \\
\text { Computer and Info Tech } \\
\text { Architecture } \\
\text { Philosophy/Religion } \\
\text { Music/Speech/Drama } \\
\text { Accounting } \\
\text { Business }\end{array}$ \\
\hline
\end{tabular}

In the "Top ten" section, majors are listed from most specific to less specific. In the "Bottom ten" section, majors are listed from least specific to more specific. That is, for occupation HHI, nursing is the most specific and environmental studies is the most general. Majors in italics appear on the same list for all three measures. Majors in bold appear on most specific and most general lists for different measures.

\section{Estimating the Return to Specialized Education}

\subsection{Data}

We use the American Community Survey (ACS) from 2009 to 2015 to estimate the returns to education specificity. Since 2009, the ACS has asked for the respondent's college major, allowing us to study earnings patterns by field of study. We keep all respondents aged 23 
to 60 with a bachelor's degree or higher and map their college majors (given in about 100 different codes) into the 51 Baccalaureate and Beyond major categories. We then merge in the four major-level measures of specificity described in Section 4.

In addition to college major for each respondent, we have gender, race/ethnicity (black, Hispanic, Asian/Pacific Islander, and other), and level of highest degree (bachelor's, master's, professional, or doctoral degree). We infer the year of college graduation based on the respondent's birth date and calculate potential experience as the current year minus the inferred graduation year.

Our main outcome of interest is annual wage and salary income, which we top-code at $\$ 500,000$. We also include the major-level SAT measures (average SAT Math and Verbal scores and the standard deviation of SAT scores) as control variables. The test scores proxy for the skill level of the major, while the standard deviation of SAT measures the variance in ability of students who enter the major. The standard deviation is included to ensure that the specificity of a major's outcomes is not merely picking up that a broad or narrow set of students enter that field. By including these measures, we can be confident that our estimated return to specificity is not driven by some majors attracting higher ability students - or a wider array of students - than others.

\subsection{Estimation}

We estimate regressions of the form:

$y_{i}=\beta_{0}+\beta_{1} \exp +\beta_{2} \exp ^{2}+\beta_{3} \operatorname{spec}_{i}+\beta_{4}$ spec $^{*} \exp +\beta_{5}$ spec $^{*} \exp ^{2}+\Gamma_{1} X_{i}+\Gamma_{2} M_{i}+\operatorname{gradyear}_{i}+$ year $_{i}$

where exp is potential experience, spec $_{i}$ is a measure of major specificity, $X_{i}$ is a set of personal characteristics including gender and race, and $M_{i}$ is a set of major characteristics apart from specificity. We also include year fixed effects and graduation year fixed effects to control for changing economic conditions, which is particularly important over this time period that includes much of the Great Recession. ${ }^{17}$

In our data, some majors have many more observations than others. ${ }^{18}$ This means

\footnotetext{
${ }^{17}$ Our results come from a combination of the Great Recession and the post-recession period. We have run all of our results for the two periods separately (e.g., 2009 to 2012 and 2013 to 2015), and our results are similar for both sub-periods.

${ }^{18}$ For instance, education/library science and business each have over 250,000 observations, while majors like public health, computer programming, and area studies have fewer than 15,000. The average number of observations for a major is about 59,000.
} 
that unweighted regressions would primarily measure the return to specificity among the large majors, while small majors would contribute little to the results. Because we want to measure the return across all majors, we weight our regressions by the inverse of the major size, which gives equal weight to all of our majors.

\subsection{Earnings Returns to Specificity}

\subsubsection{Earnings Returns: Existing Measures}

We first estimate the earnings returns to college major specificity using the three existing measures of specialization: the occupational HHI, the curriculum HHI, and the "vocational" indicator. For the first two measures, we believe we are the first to empirically estimate the returns to specificity, and we are the first to apply the vocational measure in estimating the return to four-year degrees in the United States.

We start by regressing log earnings on each measure, plus the controls.Results are presented in Table 4. The occupation HHI and vocational measures show a similar pattern: a strong initial earnings return, which declines with experience. On the other hand, the curriculum HHI shows essentially no return. 
Table 4: Earnings Return to Specificity

\begin{tabular}{|c|c|c|c|c|c|c|c|c|}
\hline & $(1)$ & $(2)$ & (3) & $\begin{array}{c}\text { pendent var } \\
(4)\end{array}$ & $\begin{array}{c}\log \text { annual } \\
(5)\end{array}$ & $(6)$ & $(7)$ & $(8)$ \\
\hline Occupation HHI & $\begin{array}{c}0.015^{* * *} \\
(0.001)\end{array}$ & $\begin{array}{c}0.072^{* * *} \\
(0.002)\end{array}$ & & & & & & \\
\hline Occ HHI* potexp & & $\begin{array}{c}-0.006^{* * *} \\
(0.000)\end{array}$ & & & & & & \\
\hline Occ HHI* potexp ${ }^{2}$ & & $\begin{array}{l}0.000^{* * *} \\
(0.000)\end{array}$ & & & & & & \\
\hline Curriculum HHI & & & $\begin{array}{c}-0.004 * * * \\
(0.001)\end{array}$ & $\begin{array}{l}-0.002 \\
(0.003)\end{array}$ & & & & \\
\hline Curr HHI* potexp & & & & $\begin{array}{c}-0.002^{* * *} \\
(0.000)\end{array}$ & & & & \\
\hline Curr HHI* potexp ${ }^{2}$ & & & & $\begin{array}{c}0.000^{* * *} \\
(0.000)\end{array}$ & & & & \\
\hline & & & & & $\begin{array}{c}-0.007 * * * \\
(0.002)\end{array}$ & $\begin{array}{c}0.180^{* * *} \\
(0.006)\end{array}$ & & \\
\hline Vocational*potexp & & & & & & $\begin{array}{l}-0.019 * * * \\
(0.001)\end{array}$ & & \\
\hline Vocational $^{*}$ potexp ${ }^{2}$ & & & & & & $\begin{array}{c}0.000^{* * *} \\
(0.000)\end{array}$ & & \\
\hline Gini & & & & & & & $\begin{array}{c}0.020^{* * *} \\
(0.002)\end{array}$ & $0.056^{* * *}$ \\
\hline Gini*potexp & & & & & & & & $\begin{array}{c}-0.004 * * * \\
(0.001)\end{array}$ \\
\hline Gini*potexp $^{2}$ & & & & & & & & $\begin{array}{c}0.000^{* * *} \\
(0.000)\end{array}$ \\
\hline Constant & $\begin{array}{l}32.304^{* * *} \\
(0.966)\end{array}$ & $\begin{array}{l}32.375 * * * \\
(0.966)\end{array}$ & $\begin{array}{l}31.112^{* * *} \\
(0.960)\end{array}$ & $\begin{array}{c}30.801 * * * \\
(0.961)\end{array}$ & $\begin{array}{l}31.111 * * * \\
(0.957)\end{array}$ & $\begin{array}{l}31.339 * * * \\
(0.957)\end{array}$ & $\begin{array}{l}32.994 * * * \\
(0.984)\end{array}$ & $\begin{array}{c}33.070 * * * \\
(0.983)\end{array}$ \\
\hline Observations & \multicolumn{8}{|c|}{$2,598,334$} \\
\hline R-squared & 0.134 & 0.134 & 0.133 & 0.133 & 0.133 & 0.134 & 0.134 & 0.134 \\
\hline
\end{tabular}

$* * * \mathrm{p}<0.01, * * \mathrm{p}<0.05, * \mathrm{p}<0.1$

All regressions also include gender, race, a quadratic in potential experience, graduation year dummies, year dummies, average SAT Math and Verbal scores in the major, and the standard

deviation of SAT scores in the major. The dependent variable is log annual wage and salary earnings. The Gini, occupation HHI, and curriculum HHI are in standard deviations, while vocational is a dummy variable. Data: ACS 2009-2015, college graduates aged 23 to 60 .

There is no particular reason why we would expect the returns to specificity to be linear, or to be constant over the life cycle. In Figures 3-5, we look at the returns to the three existing measures at different ages, in graphical form. Each figure plots the coefficient of interest from a series of regressions of log earnings, by age group. Figure 3 graphs the estimated return to vocational majors, relative to academic majors. For the continuous measures, Figures 4 and 5 show the estimated return to a dummy variable for being among the ten most specific and ten least specific (most general) majors, relative to the majors in the middle. Results are similar for narrower or broader definitions of specific majors (such as top/bottom five or top/bottom fifteen majors).

The vocational measure (Figure 3 ) shows a strong initial earnings return to vocational majors of about $15 \%$, which declines with age. By age 31-35, the return is gone, and by age 36-40, academic majors are outperforming vocational majors. This remains true throughout 
the rest of the life cycle. The story told by the vocational measure is that specific majors are best (by far) early in the life cycle, while general majors pay off more starting in a worker's 30 s.

Figure 3: Earnings Return: Vocational

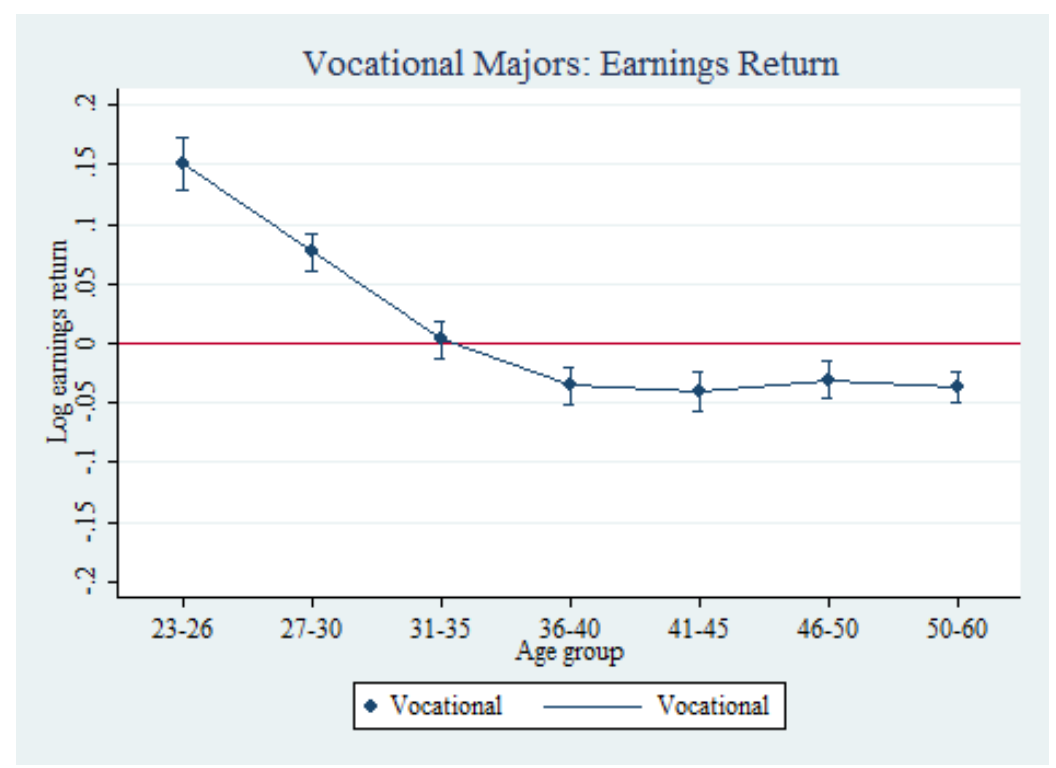

Our "vocational" measure has a very different meaning here than in papers studying European educational systems, for two reasons. First, we use college graduates only, defining vocational and general based on the college major. Second, the United States does not have a tracking or apprenticeship system as in many European countries. In our case, vocational implies that a major is closely connected to particular jobs in the labor market.

Despite these differences, our results are consistent with a recent literature estimating the returns to vocational and general education. Hanushek et al. (2017) estimate the return to vocational education in a sample of eleven European countries with sizable vocational education systems. They find that individuals with vocational education have higher employment rates early in life, but that general education becomes more valuable as the individual ages. They point to this as evidence that general education provides a less clear transition from school to work, but it provides adaptability that pays off over time. Using Swedish data on individuals in secondary school programs, Golsteyn and Stenberg (2017) find results consistent with those in Hanushek et al. (2017). Like these papers, we find that vocational majors have a large positive return early in the career, but that academic majors pay off the most 
starting in a worker's 30s.

Next we move to the two continuous measures, the occupation HHI (Figure 4) and the curriculum HHI (Figure 5). These two measures tell similar stories to each other, but the conclusion is somewhat different from the vocational measure. For the occupation HHI, the most specific majors are the best initially, although insignificantly so. By around age 30, though, general majors are performing better than specific majors. This pattern is similar to the vocational results, but the difference is that here, the most specific majors never really pay off to any signficant degree. The curriculum measure also shows that the most specific majors (barely) earn the most initially and then fall behind around age 30-35.

Figure 4: Earnings: Occupation HHI

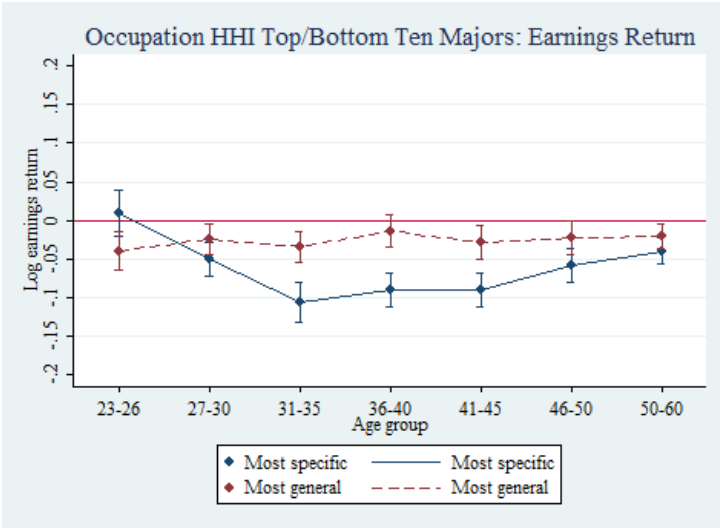

Figure 5: Earnings: Curriculum HHI

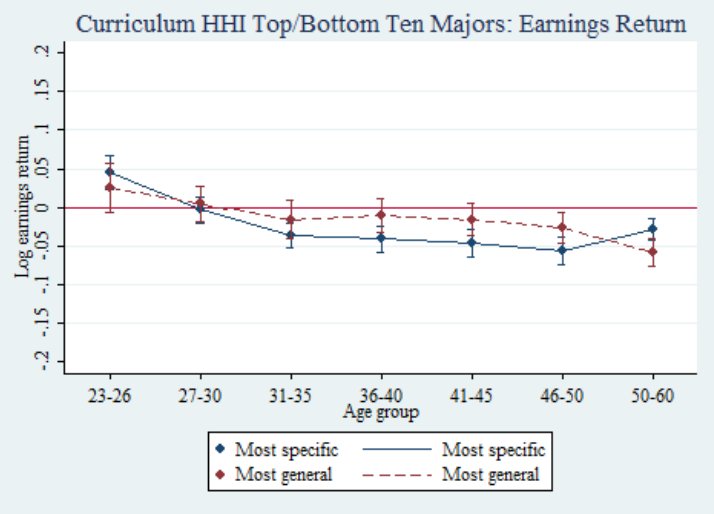

The three existing measures do not tell a fully consistent story. All three tell us that the best time to be from a specific major is early in the career, but they differ on how good that outcome is. All three also tell us that general majors are better than specific majors at most later ages. For vocational majors, the early-career advantage of specific majors is large. For the other two measures, there is little advantage to specificity at any age.

A natural follow-up question is the role of graduate degrees in this analysis. We choose not to control for graduate degrees here, instead taking the likelihood of (and return to) a graduate degree as part of the return to a major. If a major is likely to lead to a graduate degree, that is part of the return to the major and should not be controlled for separately. ${ }^{19}$ Some undergraduate majors may lead more easily to graduate school opportunities, which would potentially lower their initial return and raise their return once the student leaves graduate school. This could be particularly true for the non-vocational degrees.

\footnotetext{
${ }^{19}$ See Altonji et al. (2016) for a discussion of this issue.
} 
The first three graphs of Figure B.2 in the Appendix repeat the analysis of Figures 35 , but restrict to those without any graduate degree, essentially cutting off the returns to majors that come through graduate study. One obvious difference here is that the vocational majors now maintain their advantage over academic majors at every age. This confirms that much of the return to academic majors in the 30s and 40s comes from those who continued on to graduate study. Academic majors may lack a clear path to the labor market that hurts them initially, but through graduate study, they pay off in the long run. For the other two measures, the conclusions are largely unchanged when excluding graduate degrees.

\subsubsection{Earnings Returns: Gini Measure}

We now estimate the return to college major specificity using our new measure, the Gini coefficient. The last two columns of Table 4 show that more specific majors have an initial earnings return of about $6 \%$ per standard deviation, which fades slowly with age. This is the same pattern seen in the vocational and occupation HHI measures.

Figure 6 shows the earnings estimates for the top ten and bottom ten most specific majors according to the Gini measure. The results are quite different from those of the existing measures. The most specific majors earn an initial premium of about $8 \%$. This declines with age, and is gone by age 31-35, but the point estimates are positive again for later ages. At no point do general majors, or even the average majors, do significantly better than the most specific majors. The most general majors are always worse than both the specific majors and the average majors.

While the "shape" of the specific major line is similar to the vocational results in Figure 3 , the conclusion is quite different. With a vocational classification, general majors paid off more starting in the worker's 30s, giving a tradeoff between what majors were good early in the career and what majors were good later in the career. Here, there is no such tradeoff. There is no age at which it starts paying to be from a more general major. Specific majors seem to be clearly the best bet over the course of a lifetime. 
Figure 6: Earnings Return: Gini

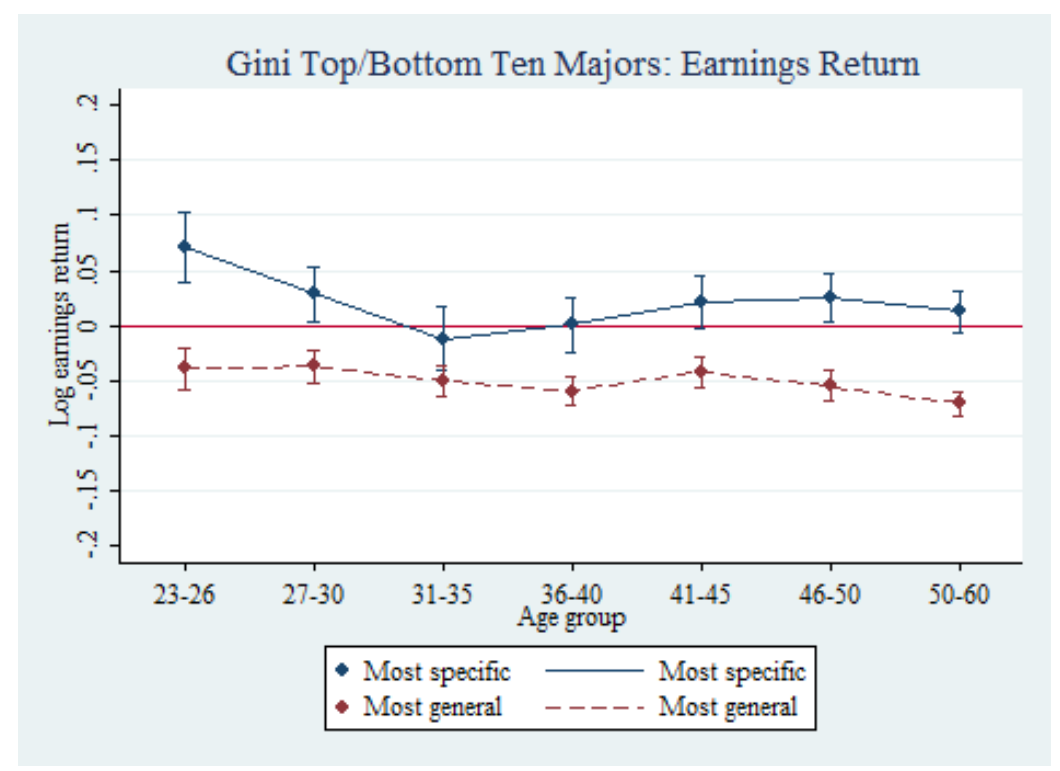

As with the other measures, we also include results that exclude graduate degrees in Figure B.2 in the Appendix. The result for specific majors is nearly identical. The only difference is that the most general majors do better when graduate degrees are excluded, which is the reverse of what happened with academic majors in Figure 3.

To ensure that these estimates are robust to different cutoffs, we also present the Gini results for the top and bottom five majors (Figure B.3 in the Appendix) and the top and bottom third of majors (Figure B.4 in the Appendix). ${ }^{20}$ The pattern for the top and bottom five majors is broadly similar to the top and bottom ten. The initial premium for specific majors is a bit larger (10\% instead of $8 \%)$, so the initial advantage of specific fields is even larger among the very most specific majors. The five most specific majors earn more than the average major at every age, but the five most general majors also do well relative to average. It is still clear that the most specific majors are the best bet, but it is less clear here that general majors are a bad bet.

When the definition is broadened to the top and bottom third of majors (with 17 majors in each category), specific majors look even better, as they are the highest-paying at every age. Here again, general majors also do well compared to the majors that are neither highly specific nor highly general.

\footnotetext{
${ }^{20}$ With 51 majors, each third has 17 majors.
} 
We have two main conclusions from these Gini results. First, there is a strong return to more specific majors - that is, those that provide specific skills. The initial premium is about $6 \%$ per standard deviation, and the most specific ten majors earn about $8 \%$ more than average majors from ages 23-26. This initial premium persists and stays positive throughout most of the life cycle. Results vary some as the definition of "most specific" is broadened, but the conclusion that the most specific majors outperform other majors at most ages is unchanged. This result differs from conventional wisdom and from the results of the existing measures, which showed that specific majors earned an initial premium but later fell behind more general majors. It also differs from the vocational results in Europe (Hanushek et al. (2017), Golsteyn and Stenberg (2017)). In these results, there is a tradeoff between the early-career premium and a later penalty. There is no such tradeoff in our Gini results.

Second, the return to specificity seems to be nonlinear, as the majors that provide the most transferable skills also sometimes do better than the majors that are neither general nor specific.

We also note again here that our Gini measure is only weakly correlated with average SAT scores $(\rho=0.095$ with math scores and $\rho=-0.133)$. In fact, it is less strongly correlated with SAT scores than any of the four measures of specificity. It is possible that our Gini measure is correlated with something else we do not include that determines pay. However, given the very weak correlations with SAT scores, this is not likely. We are confident that our finding of the most specific majors bringing the highest earnings is not simply picking up other factors correlated with specificity.

\subsection{Decomposing Earnings Returns: Hours, Wages, and Em- ployment}

Earnings returns could come through effects on employment and hours worked or through effects on earning power (hourly wages). In this section, we look at various mechanisms that contribute to the return to specific and general majors. On the one hand, a specialized skill set could make an individual more attractive to employers, if that skill set is well-aligned to the needs of the firm. On the other hand, a specialized worker with less transferable skills may have a harder time finding a good occupational match, and may therefore spend more time searching for a job than a generally skilled worker. Those from specific majors also may be more vulnerable to unemployment from sector-specific shocks. In the sections below 
we present the hours and hourly wage returns of the most specific and general majors, as well as the effect of specificity on the probability of employment.

\subsubsection{Hours}

Annual earnings, annual weeks worked, and usual hours per week are provided in the ACS data. We can therefore look at annual hours (weeks worked times usual hours per week) and wages (earnings divided by hours).

Figure 7 gives the hours returns to the top and bottom ten majors of specificity, measured using the four approaches (except for vocational, which is a dummy variable). These results give some indication of the employment return to specificity on the intensive margin: conditional on working, are graduates from specialized majors working more, or working less?

Figure 7: Log hours return to specificity

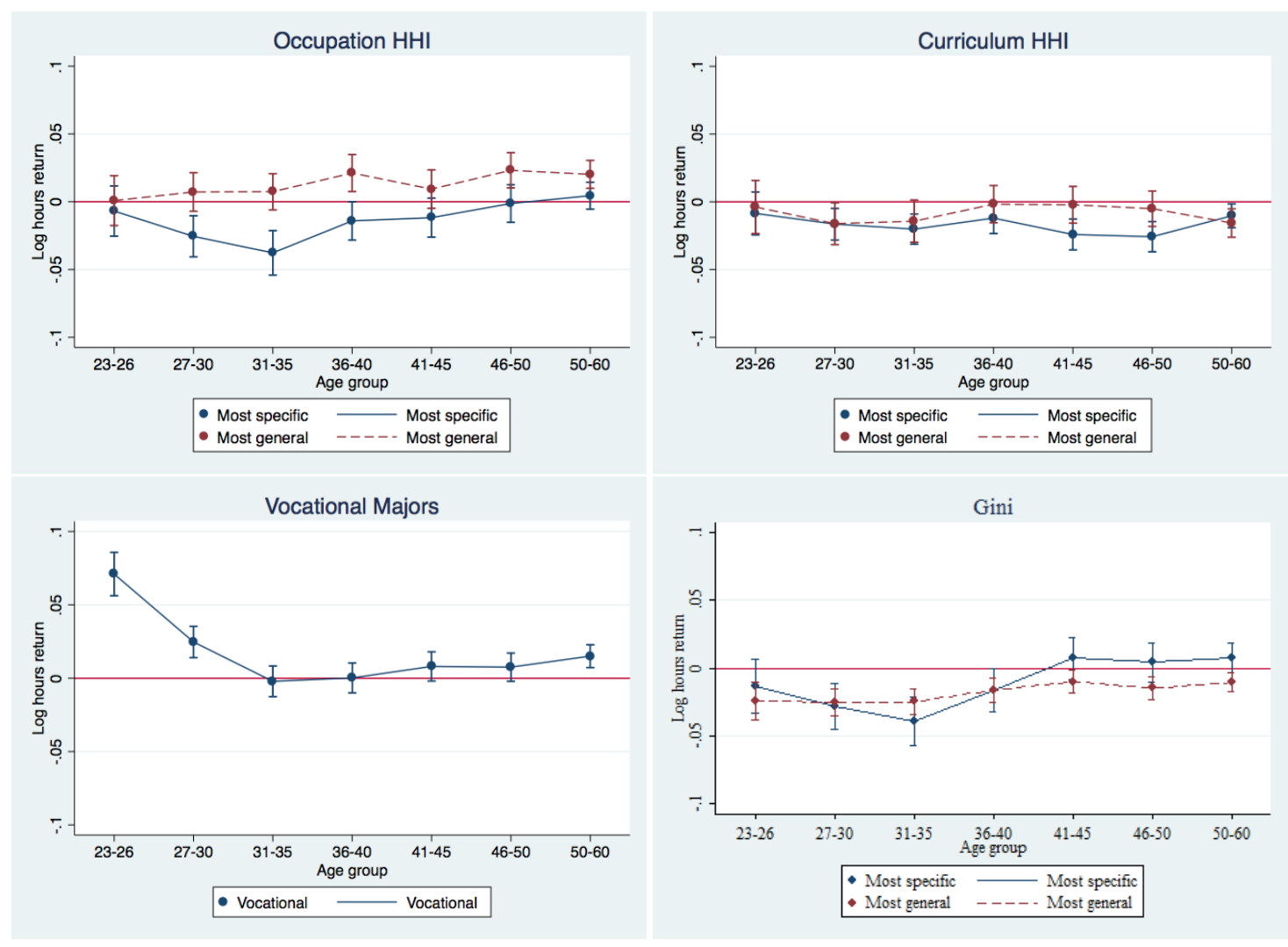

Vocational majors enjoy a $7 \%$ hours premium for ages $23-26$, and while this fades by the 
30s, the point estimates never turn negative. The HHI measures show little difference in hours between the major categories, although the occupation HHI shows that more specific majors work slightly fewer hours from age 27-40.

For our preferred measure, the Gini coefficient, we see a surprising result. Specific majors, which enjoyed an earnings premium early in the career, actually suffer an hours penalty of about $3-4 \%$ (relative to the average majors) for the late 20 s through age 40 . At the youngest ages, when the most specific majors earned an $8 \%$ premium, they have no hours premium. As we will verify below, this tells us that the earnings advantage of the most specific majors comes entirely through earning power rather than employment.

\subsubsection{Wages}

Figure 8 looks at hourly wages. Vocational majors, in addition to having an hours advantage over academic majors, also have a wage advantage. Their large initial earnings premium comes $40 \%$ through hours and $60 \%$ through wages. Given that vocational majors are thought to have a clearer path to the labor market, the hours advantage is not surprising. It is perhaps surprising that most of the earnings effect is through wages. Similar to the earnings result, however, the wage advantage of vocational majors fades by the worker's 30s, and academic majors earn more per hour from that point on.

For Gini, the results are rather stark. The most specific majors had an initial earnings advantage, and now we see that all of this comes through earning power rather than employment. The wage advantage of specific majors is positive throughout the life cycle and significant at most ages. Majors with specialized skills are not better suited for finding a job, but the jobs they find are significantly higher-paying. Majors with transferable skills, on the other hand, have lower earning power than specific or average majors at every age.

\subsubsection{Unemployment probability}

Because analysis of log hours only includes those who worked some positive number of hours, we also look at the probability of unemployment. We are interested in knowing if some majors are more vulnerable to periods of unemployment, as the unemployment rate is a commonly used measure of labor market outcomes for college graduates. Unemployment is defined the usual way here, meaning that the person is out of work and is looking for work. ${ }^{21}$

\footnotetext{
${ }^{21}$ Results are similar when looking at the probability of employment.
} 
Figure 8: Wage return to specificity

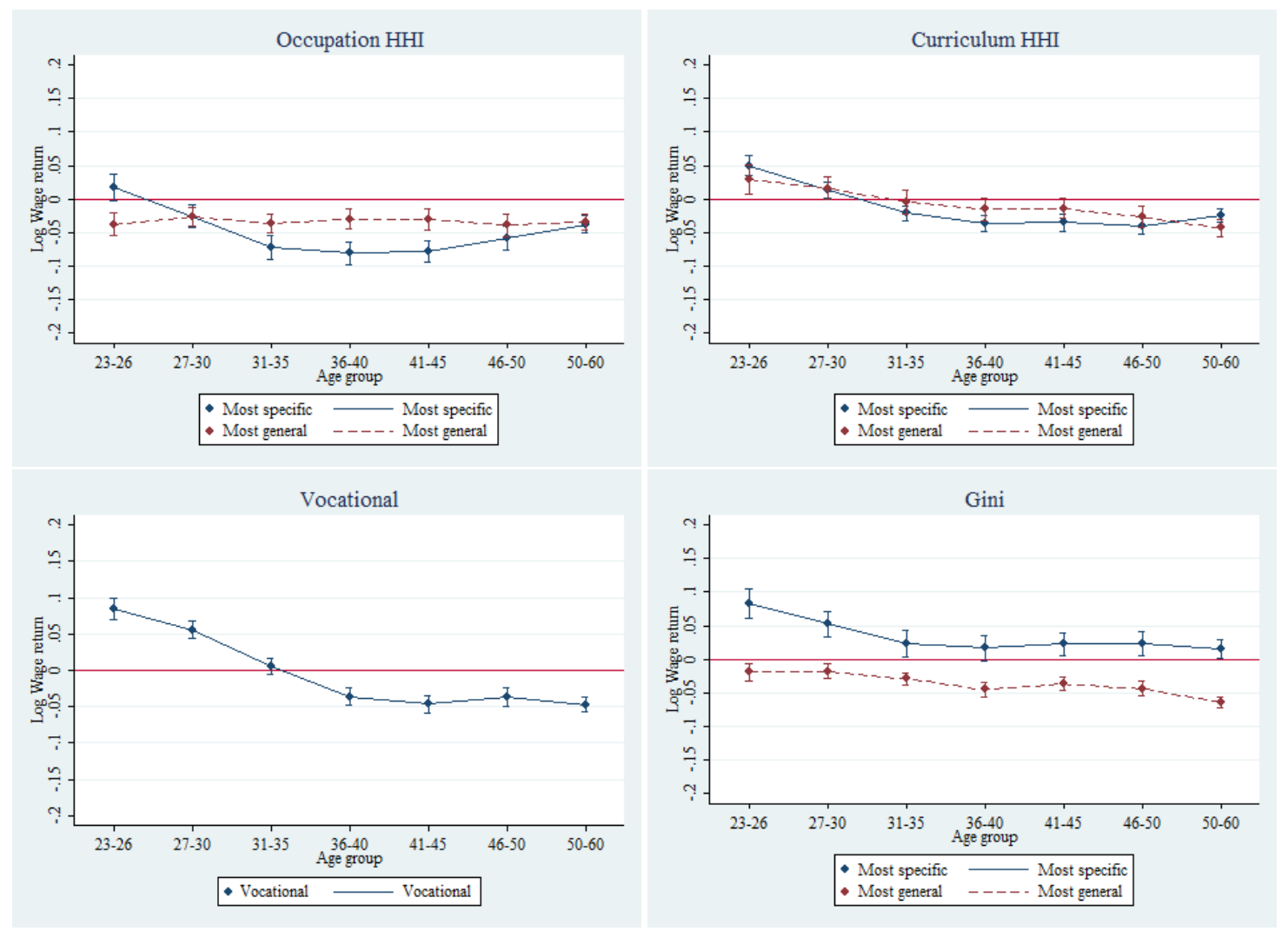

While hours and earnings are annual measures, unemployment is a snapshot measure and is defined as being out of work but looking for work at the time of the survey. Thus, unemployment is not directly comparable with the other outcomes.

Figure 9 presents the unemployment probability "return" for our four measures of specificity over the life cycle. A negative return means that graduates from the major are less likely to be unemployed. While the magnitude of the effects is small, there are some discernible patterns. For vocational majors, the results here align perfectly with the hours and earnings results. Vocational major graduates not only work more hours than academic majors at early ages, but are also less likely to be unemployed.

For the Gini measure, the results are more consistent with the earnings results than with the hours results. Recall that specific majors, according to Gini, earn the most but work fewer hours. Here, we see that specific majors are less likely to be unemployed (by about 0.5 percentage point) at most ages. 
Figure 9: Unemployment "return" to specificity

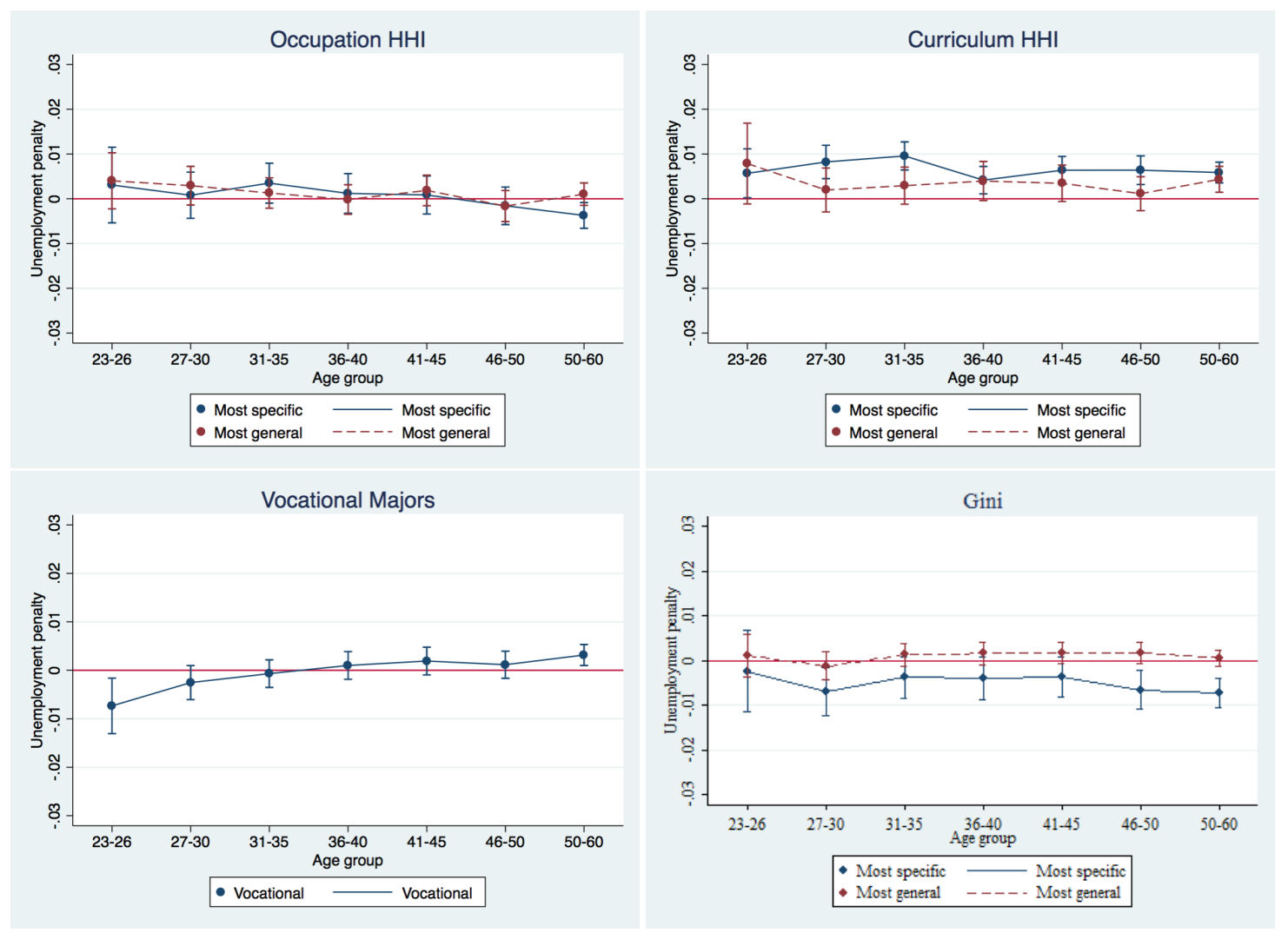

\subsection{Entrepreneurs and Managers}

An important branch of the literature on skill specificity is focused on the relationship between breadth of human capital and entrepreneurship. A prominent hypothesis, the "jackof-all-trades" theory, predicts that those with more general or varied skills are best suited to entrepreneurship, which requires competence in a variety of skills rather than mastery of a single skill.

Lazear (2005) pioneered this field of research by looking at Stanford Business School MBA graduates, from which he found two pieces of evidence in support of the jack-of-alltrades theory. First, those who took a more balanced MBA curriculum were more likely to become entrepreneurs, and second, the same was true of those who had held more different jobs before going to business school. Other research has shown similar findings, primarily focusing on the prior job roles held by those who become entrepreneurs (e.g., Wagner (2006)).

More recently, Lazear has advanced the importance of balanced skills for leadership 
within a firm (2012). Frederiksen and Kato (2017) find evidence that human capital breadth, defined in this case as the number of prior roles, is important for securing top management positions. These papers extend the argument for broad education beyond entrepreneurs, to those holding managerial roles - regardless of whether those roles are in self-employment or not.

For data availability reasons, studying the link between the specificity of one's education and the likelihood of entrepreneurship or managerial roles is more difficult than studying the link between prior job roles and these outcomes. Lazear (2005) had access to detailed curricula for the MBA students, but this is likely not representative of the broader population. Fortunately, with our method of characterizing college degrees as specific or general, we can do this for all fields at once.

We use our Gini measure of specificity to explore the hypothesis that general education is associated with a higher probability of being an entrepreneur, or of holding a managerial occupation. We define entrepreneurs as those respondents who report income from selfemployment, including negative income. Managers are defined based on occupation codes in the $\mathrm{ACS}^{22}$

First, we simply check correlations. In our data, the correlation between the worker's major's Gini measure and the probability of being an entrepreneur is -0.04; for the probability of being a manager, it is $-0.06 .^{23}$ Graduates from more specific majors are less likely to become either entrepreneurs or managers. As with all of our results, however, it is useful to look at the top and bottom majors to check for nonlinear effects.

Figure 10 repeats our primary analysis, with the dependent variable now the a binary indicator for being an entrepreneur. ${ }^{24}$ The results are quite striking: graduates from the most specialized majors are consistently less likely than more general graduates to become entrepreneurs, with the effect increasing as workers age. In contrast, and in keeping with Lazear (2005)'s predictions, graduates from the most general majors are slightly more likely to become entrepreneurs. ${ }^{25}$

\footnotetext{
${ }^{22}$ We present only the results using our Gini measure here: Figures B.5 and B.6 in the Appendix show the manager and entrepreneur return for all four measures of specificity.

${ }^{23}$ See Table B.1 for correlations between these indicators and all four specificity measures.

${ }^{24}$ Unlike the earnings results, Figures 10 and 11 are results from probit regressions, and we graph the marginal effects.

${ }^{25}$ We have also measured entrepreneurship using an indicator for whether the person reports being selfemployed. The correlation between Gini and this measure is the same as for the income-based measure we use (-0.04), and results for the most specific majors are nearly identical. Our finding that the most general majors are the most likely to enter entrepreneurship is more dependent on the definition we use.
} 
Figure 10: Entrepreneurship and specificity

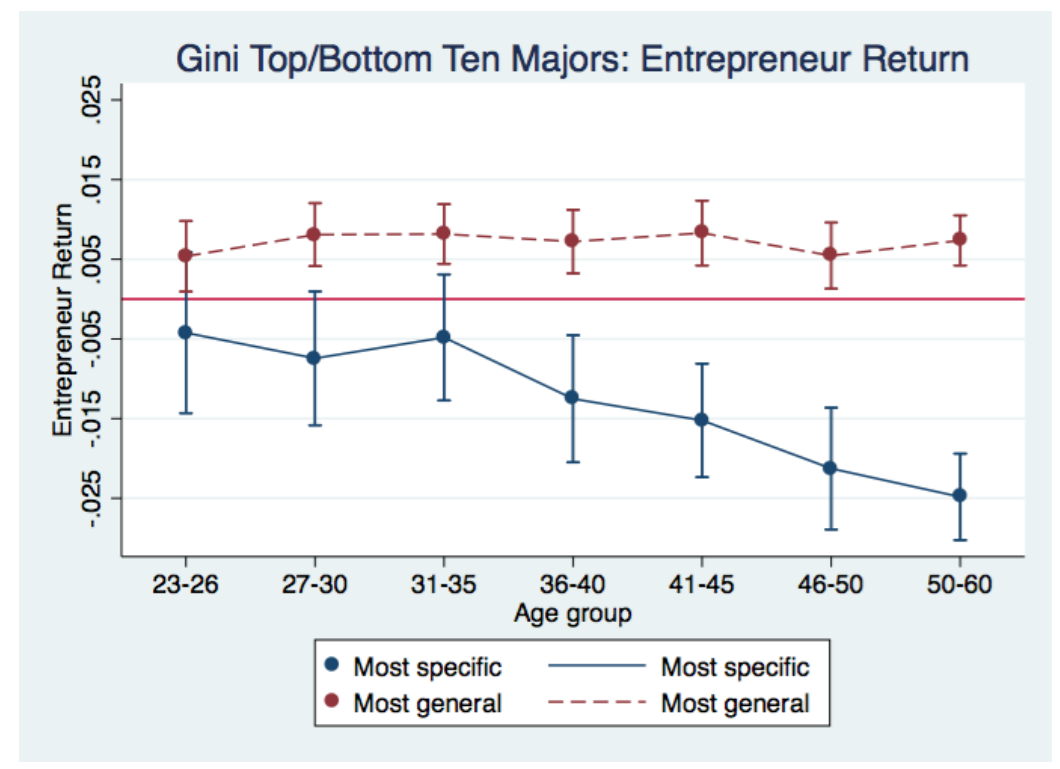

Given that only $12 \%$ of our sample reports any business income at ages $50-60$, the effect of being in a very specific or general major on this indicator is substantial. The effect of graduating with one of the ten most specific majors corresponds to about a $21 \%$ decline in the likelihood of being an entrepreneur at these ages.

Figure 11 carries out the same analysis for the probability of holding a managerial occupation. Managers are more common than entrepreneurs: $16 \%$ of our sample is employed in managerial occupations. A similar pattern holds for managers as for entrepreneurs: the most specialized majors are strongly negatively associated with managerial positions. The effect is about a $25 \%$ drop in the probability of being a manager and is consistent throughout the career. In contrast to entrepreneurs, we find no evidence that the most general majors confer any advantage with respect to the average majors - but graduates from general majors are clearly more likely to become managers than are their specialized peers.

To better mirror the approach of Lazear (2005), who looked at the variety of courses taken by the MBA graduates, we also perform this analysis for the curriculum HHI measure of specificity (see Figure B.5 in the Appendix). Surprisingly, here we find the opposite of what he found. The most specific majors by this measure are the most likely to enter entrepreneurship. It is important to note that our approach here remains distinctly different from Lazear's: while he was looking at individual-level specialization within a given field 
Figure 11: Managers and specificity

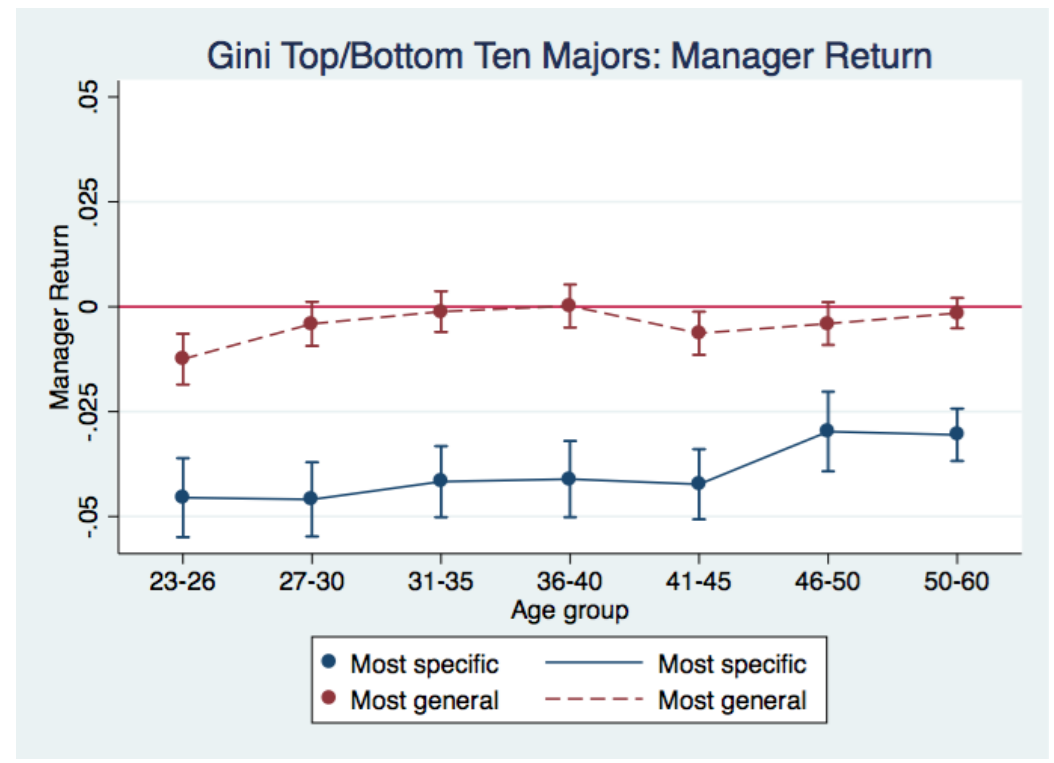

of study (MBA students), we are looking at average levels of specialization across fields. What our results do show is that graduating from a major that displays specialized skills, as measured by Gini, is negatively associated with entrepreneurship, while being from a major with only a small variety of courses is not.

\section{Conclusion}

The growing literature on the determinants and labor market impacts of college major choice has generated new insights on how students select their field of study, and how this choice affects earnings over the lifecycle (see Altonji et al. (2015)). Systematic differences in college major choice across genders (Brown and Corcoran (1997)) and ethnic groups (Arcidiacono et al. $(2016,2012))$ make it all the more important to understand where differences in returns to field of study come from. One characteristic which differs substantially across fields of study is the level of specialization of college degrees. This paper has presented new evidence on the return to specialization in higher education, as well as shedding light on the the strengths and weaknesses of available measures used to capture educational specialization.

One of our primary contributions is developing a new way to measure the specialization of a college major, based on the transferability of skills. This aligns with the theoretical 
underpinnings of general and specific human capital in the tradition of labor economics. By measuring inequality of earnings within a major across occupations using a Gini coefficient, we identify the majors that provide specialized and general skills. We argue that this theorydriven measure is superior to existing ad-hoc measures.

Using our preferred measure of specificity, we find that specific majors pay off the most at almost every age. Unlike results using existing measures of specificity, there is no tradeoff between early- and late-career success. The most specific majors are always better than the most general majors, and usually better than average majors as well. All of this earnings premium seems to come through higher earning power rather than working more hours.

While there is a much higher return to specialized skills than to transferable, flexible skills, we do find evidence that broadly-educated workers are more likely to have their own business, and also more likely to hold managerial occupations. The most general majors, meanwhile, lead to the highest rates of entrepreneurship. This lends support to the prominent "jack-of-all-trades" theory of entrepreneurship and managerial ability.

We also find a large early-career premium to "vocational" majors, which fades and changes sign by the worker's mid-30s. This initial premium is driven by advantages in both wages and hours. These majors not only offer a clear path to the labor market but also higher earning power early in the career. For the other two measures we look at, specific majors earn adequately at first but quickly fall behind more general majors.

Our results suggest that a broad class of existing measures yield similar estimates of the return to specialization; however, even these measures agree only weakly on which majors are the most and least specialized. Furthermore, the new theory-driven Gini measure we propose behaves quite differently than the existing measures. This divergence demonstrates how the return to specificity depends critically on how one defines and measures it. 


\section{References}

Aliaga, R. And S. Montoya (1999): "GINIDESC: Stata module to compute Gini index with within- and between-group inequality decomposition," Tech. rep.

Altonji, J., P. Arcidiacono, And A. Maurel (2015): "The Analysis of Field Choice in College and Graduate School: Determinants and Wage Effects," Tech. rep., National Bureau of Economic Research, Cambridge, MA, Cambridge, MA.

Altonji, J. G., E. Blom, And C. Meghir (2012): "Heterogeneity in human capital investments: High school curriculum, college major, and careers," Annual Review of Economics, 4, 185-223.

Altonji, J. G., L. B. Kahn, And J. D. Speer (2016): "Cashier or Consultant? Entry Labor Market Conditions, Field of Study, and Career Success," Journal of Labor Economics, 34, S361-S401.

Altonji, J. G. And R. A. Shakotko (1987): "Do Wages Rise with Job Seniority?" The Review of Economic Studies, 54, 437-459.

Arcidiacono, P., E. M. Aucejo, And V. J. Hotz (2016): "University Differences in the Graduation of Minorities in STEM Fields: Evidence from California," American Economic Review, 106, 525-562.

Arcidiacono, P., E. M. Aucejo, And K. Spenner (2012): "What happens after enrollment? An analysis of the time path of racial differences in GPA and major choice," IZA Journal of Labor Economics, 1, 5.

Artz, G., K. L. Kimle, And P. F. Orazem (2014): "Does the Jack of All Trades Hold the Winning Hand? Comparing the Role of Specialized versus General Skills in the Returns to an Agricultural Degree," American Journal of Agricultural Economics, 96, 193-212.

Becker, G. S. (1962): "Investment in human capital: a theoretical analysis," The Journal of Political Economy, 9-49.

Blom, E., B. C. Cadena, And B. J. Keys (2015): "Investment over the Business Cycle: Insights from College Major Choice," IZA Discussion Papers, 1-58. 
Borghans, L. And B. H. H. Golsteyn (2007): "Skill transferability, regret and mobility," Applied Economics, 39, 1663-1677.

Bridet, L. AND M. Leighton (2015): “The Major Decision: Labor Market Implications of the Timing of Specialization in College," Working paper, 1-74.

Brown, C. And M. Corcoran (1997): "Sex-Based Differences in School Content and the Male-Female Wage Gap," Journal of Labor Economics, 15, 431-465.

Brunello, G. And L. Rocco (2017): "The Labor Market Effects of Academic and Vocational Education over the Life Cycle: Evidence Based on a British Cohort," Journal of Human Capital, 11, 106-166.

Bureau of Labor Statistics (2000): "2000 Standard Occupational Classification (SOC) User Guide," .

Carnevale, A. P., B. Cheah, and J. Strohl (2012): "Hard Times, College Majors, Unemployment and Earnings: Not All College Degrees Are Created Equal.” Georgetown University Center on Education and the Workforce.

Chevalier, A. (2011): "Subject choice and earnings of UK graduates," Economics of Education Review, 30, 1187-1201.

Coenen, J., H. Heijke, And C. Meng (2015): "The labour market position of narrow versus broad vocational education programmes," Empirical Research in Vocational Education and Training, 7, 1-31.

Cowell, F. (2011): Measuring Inequality, Oxford University Press.

Cowell, F. A. (2000): "Measurement of Inequality," in Handbook of Income Distribution, 87-166.

Dolton, P. And A. Vignoles (2002): "Is a broader curriculum better?" Economics of Education Review, 21, 415-429.

Frederiksen, A. And T. Kato (2017): "Human Capital and Career Success: Evidence from Linked Employer-Employee Data," The Economic Journal, 48, 443-31.

Gibbons, R. And M. Waldman (2004): “Task-specific human capital," American Economic Review, 203-207. 
Golsteyn, B. And A. Stenberg (2017): "Earnings Over the Life Course: General versus Vocational Education," Journal of Human Capital.

HALL, C. (2013): "Does more general education reduce the risk of future unemployment? Evidence from labor market experiences during the Great Recession," Working paper.

Hanushek, E. A., G. Schwerdt, L. Woessmann, and L. Zhang (2017): "General Education, Vocational Education, and Labor-Market Outcomes over the Life-Cycle," Journal of Human Resources, 1, 49-88.

Hartog, J. AND W. Vijverberg (2007): "Schools, skills and risk," Economics of Education Review, 759-771.

Hastings, J. S., C. A. Neilson, And S. D. Zimmerman (2013): "Are Some Degrees Worth More than Others? Evidence from college admission cutoffs in Chile," Working paper.

JANN, B. (2013): "COEFPLOT: Stata module to plot regression coefficients and other results," Tech. rep.

Kambourov, G. And I. Manovskit (2009): "Occupational specificity of human capital*," International Economic Review, 50, 63-115.

Kinsler, J. AND R. PAVAN (2015): "The specificity of general human capital: Evidence from college major choice," Journal of Labor Economics, 33, 933-972.

Kirkebøen, L. J., E. Leuven, And M. Mogstad (2016): "Field of Study, Earnings, and Self-Selection," The Quarterly Journal of Economics, 131, 1057-1111.

Kreisman, D. And K. Stange (2017): "Vocational and Career Tech Education in American High Schools: The Value of Depth Over Breadth," NBER Working Paper.

LAZEAR, E. (2005): "Entrepreneurship," Journal of Labor Economics.

LAzEAR, E. P. (2012): "Leadership: A personnel economics approach," Labour Economics, 19, 92-101.

Lemieux, T. (2014): "Occupations, fields of study and returns to education," Canadian Journal of Economics/Revue canadienne d'économique, 47, 1047-1077. 
Liu, K., K. G. Salvanes, And E. Ø. Sørensen (2016): "Good skills in bad times: Cyclical skill mismatch and the long-term effects of graduating in a recession," European Economic Review, 84, 3-17.

Malamud, O. (2010): "Breadth versus Depth: The Timing of Specialization in Higher Education," Labour, 24, 359-390.

(2012): "The Effect of Curriculum Breadth and General Skills on Unemployment," Working paper, 1-47.

Morris, J. (1973): "Educational Training and Careers of PH. D. Holders. ," Tech. rep.

NeAL, D. (1995): "Industry-specific human capital: Evidence from displaced workers," Journal of Labor Economics, 653-677.

PArey, M. (2016): "Vocational Schooling versus Apprenticeship Training. Evidence from Vacancy Data," Conference paper, 1-44.

Peri, G., K. Shih, And C. Sparber (2015): "STEM workers, H-1B visas, and productivity in US cities," Journal of Labor Economics, 33, S225-S255.

Poletaev, M. And C. Robinson (2008): "Human capital specificity: evidence from the Dictionary of Occupational Titles and Displaced Worker Surveys, 1984-2000," Journal of Labor Economics, 26, 387-420.

RAKitAn, T. J. AND G. M. ARTZ (2015): "What good are skills, anyway? Estimating the returns to specific skills in a college education," Working paper, 1-25.

Saniter, N. And T. Siedler (2014): "Door Opener or Waste of Time? The Effects of Student Internships on Labor Market Outcomes," Working paper.

Sellami, S., D. Verhaest, and W. Van Trier (2016): "How to measure field-of-study mismatch? A comparative analysis of the different methods," Working paper, 1-38.

Silos, P. And E. Smith (2015): "Human capital portfolios," Review of Economic Dynamics, $18,635-652$

SiLvA, O. (2007): "The Jack-of-All-Trades entrepreneur: Innate talent or acquired skill?" Economics Letters, 97, 118-123. 
Stevens, A. H., M. Kurlaender, And M. Grosz (2015): "Career Technical Education and Labor Market Outcomes: Evidence from California Community Colleges," NBER Working Paper.

Stuetzer, M., M. Goethner, And U. Cantner (2012): "Do balanced skills help nascent entrepreneurs to make progress in the venture creation process?" Economics Letters, 117, $186-188$.

TChuente, G. (2016): "High school human capital portfolio and college outcomes," Journal of Human Capital, 10, 267-302.

WAGNER, J. (2006): “Are nascent entrepreneurs 'Jacks-of-all-trades'? A test of Lazear's theory of entrepreneurship with German data," Applied Economics, 38, 2415-2419.

WALKeR, I. AND Y. Zhu (2011): "Differences by degree: Evidence of the net financial rates of return to undergraduate study for England and Wales," Economics of Education Review, 30, 1177-1186. 


\section{A Data Appendix}

\section{A.1 Major and occupation categories}

Table A.1 lists the 51 major categories we use. For each major, we list whether the major is vocational or not (using the NCES list), and the major's rank by the occupation HHI, curriculum HHI, and Gini measures. A rank of "1" means the major is the most specific by that measure. Occupation HHI and Gini are calculated using the American Community Survey with workers aged 25-35, while the curriculum HHI is calculated from the 1993/2003 Baccalaureate and Beyond data. In the ACS, we map the field of degree variable into these 51 categories using our own crosswalk. In calculating the curriculum HHI measure, we use the total credits ("TCRED") variables to form the HHI for each major. 
Table A.1: Major Categories, with Ranks by Each Specificity Measure

\begin{tabular}{|c|c|c|c|c|}
\hline Major & Vocational? & Occ HHI rank & Course HHI rank & Gini rank \\
\hline Nursing & Yes & 1 & 5 & 1 \\
\hline Computer Programming & Yes & 10 & 46 & 2 \\
\hline Economics & No & 38 & 43 & 3 \\
\hline Secondary Education & Yes & 3 & 50 & 4 \\
\hline Finance & No & 17 & 34 & 5 \\
\hline Medical Tech & Yes & 7 & 18 & 6 \\
\hline Chemical Engineering & Yes & 20 & 2 & 7 \\
\hline Family and Consumer Science & Yes & 24 & 27 & 8 \\
\hline Library Science and Non-Secondary Education & Yes & 2 & 39 & 9 \\
\hline Other Medical/Health Services & Yes & 23 & 21 & 10 \\
\hline Mechanical Engineering & Yes & 14 & 7 & 11 \\
\hline Chemistry & No & 16 & 20 & 12 \\
\hline Biological Sciences & No & 25 & 19 & 13 \\
\hline Precision Production and Industrial Arts & Yes & 15 & 9 & 14 \\
\hline Commercial Art and Design & Yes & 5 & 6 & 15 \\
\hline Electrical Engineering & Yes & 12 & 11 & 16 \\
\hline Public Administration and Law & Yes & 29 & 17 & 17 \\
\hline Agriculture and Agr. Science & Yes & 44 & 36 & 18 \\
\hline Marketing & Yes & 30 & 40 & 19 \\
\hline Foreign Language & No & 28 & 16 & 20 \\
\hline Public Health & Yes & 47 & 15 & 21 \\
\hline Physics & No & 13 & 37 & 22 \\
\hline Civil Engineering & Yes & 6 & 4 & 23 \\
\hline Film and Other Arts & No & 45 & 1 & 24 \\
\hline Multidisciplinary or General Science & No & 46 & 45 & 25 \\
\hline Social Work and Human Resources & Yes & 9 & 10 & 26 \\
\hline Area, Ethnic, and Civic Studies & No & 42 & 38 & 27 \\
\hline Earth and Other Physical Sci & No & 22 & 26 & 28 \\
\hline Engineering Tech & Yes & 31 & 44 & 29 \\
\hline Protective Services & Yes & 27 & 8 & 30 \\
\hline Journalism & Yes & 39 & 24 & 31 \\
\hline Fitness and Nutrition & Yes & 41 & 48 & 32 \\
\hline Art History and Fine Arts & No & 33 & 13 & 33 \\
\hline English, Letters, and Literature & No & 36 & 25 & 34 \\
\hline Leisure Studies and Basic Skills & Yes & 37 & 41 & 35 \\
\hline International Relations & No & 40 & 23 & 36 \\
\hline History & No & 35 & 28 & 37 \\
\hline All Other Engineering & Yes & 21 & 12 & 38 \\
\hline Political Science & No & 19 & 22 & 39 \\
\hline Psychology & No & 34 & 33 & 40 \\
\hline Communications & Yes & 50 & 32 & 41 \\
\hline Business Management and Administration & Yes & 43 & 42 & 42 \\
\hline Accounting & Yes & 4 & 35 & 43 \\
\hline Music and Speech/Drama & No & 32 & 14 & 44 \\
\hline Philosophy and Religion & No & 26 & 31 & 45 \\
\hline Architecture & Yes & 8 & 3 & 46 \\
\hline Computer and Info Tech & Yes & 11 & 49 & 47 \\
\hline Mathematics & No & 18 & 51 & 48 \\
\hline Misc. Business and Medical Support & Yes & 48 & 47 & 49 \\
\hline Environmental Studies & No & 51 & 29 & 50 \\
\hline Other Social Sciences & No & 49 & 30 & 51 \\
\hline
\end{tabular}

Table A.2 lists the 12 coarse occupation categories we use to calculate the Gini index. 
These categories are taken from in the Baccalaureate and Beyond data. ${ }^{26}$ We map the year 2000 Standard Occupational Classication (SOC) codes (Bureau of Labor Statistics (2000)) in the American Community Survey occupations into these categories, as demonstrated in Table A.2. In calculating the Gini, we omit the final category ("Other/military").

\section{Table A.2: 12 Occupation Categories}

\begin{tabular}{|c|c|c|}
\hline B\&B Category & SOC Codes & SOC Description \\
\hline 1. Educators & 25 & Education, Training, \& Library Occupations \\
\hline \multirow[t]{2}{*}{ 2. Business/management } & 11 & Management Occupations \\
\hline & 13 & Business \& Financial Operations \\
\hline 3. Engineering/architecture & 17 & Architecture \& Engineering Occupations \\
\hline 4. Computer science & 15 & Computer \& Mathematical Occupations \\
\hline \multirow[t]{2}{*}{ 5. Medical professions } & 29 & Healthcare Practitioners and Technical \\
\hline & 31 & Healthcare Support Occupations \\
\hline 6. Editors/writers/performers & 27 & Arts, Design, Entertainment, Sports, \& Media \\
\hline \multirow[t]{3}{*}{ 7. Human/protective services/legal professionals } & 21 & Community \& Social Services Occupations \\
\hline & 23 & Legal Occupations \\
\hline & 33 & Protective Service Occupations \\
\hline 8. Research/scientists/technical & 19 & Life, Physical, \& Social Science Occupations \\
\hline 9. Administrative/clerical/legal support & 43 & Office and Administrative Support Occupations \\
\hline \multirow[t]{3}{*}{ 10. Mechanics/laborers } & 47 & Construction and Extraction Occupations \\
\hline & 49 & Installation, Maintenance, and Repair \\
\hline & 51 & Production Occupations \\
\hline \multirow[t]{5}{*}{ 11. Service industries } & 35 & Food Preparation \& Serving Related \\
\hline & 37 & Building and Grounds Cleaning \& Maintenance \\
\hline & 39 & Personal Care and Service Occupations \\
\hline & 41 & Sales and Related Occupations \\
\hline & 53 & Transportation \& Material Moving \\
\hline \multirow[t]{2}{*}{ 12. Other/military } & 45 & Farming, Fishing, and Forestry Occupations \\
\hline & 55 & Military Specific Occupations \\
\hline
\end{tabular}

\footnotetext{
${ }^{26}$ We use the coding for the variable B3OCCAT, which is mapped to other occupation categorizations within that dataset.
} 


\section{B Appendix Figures}

Figure B.1 overlays major-occupation cell average SAT math scores on top of normalized earnings, for the six example cases shown in Figure 2. Cell-average SAT math scores are normalized by dividing by the mean value at the cell level, so that a value of 1 corresponds the the average cell-level value of SAT math scores.

Figure B.1: Example of general and specific majors, with cell-average SAT math

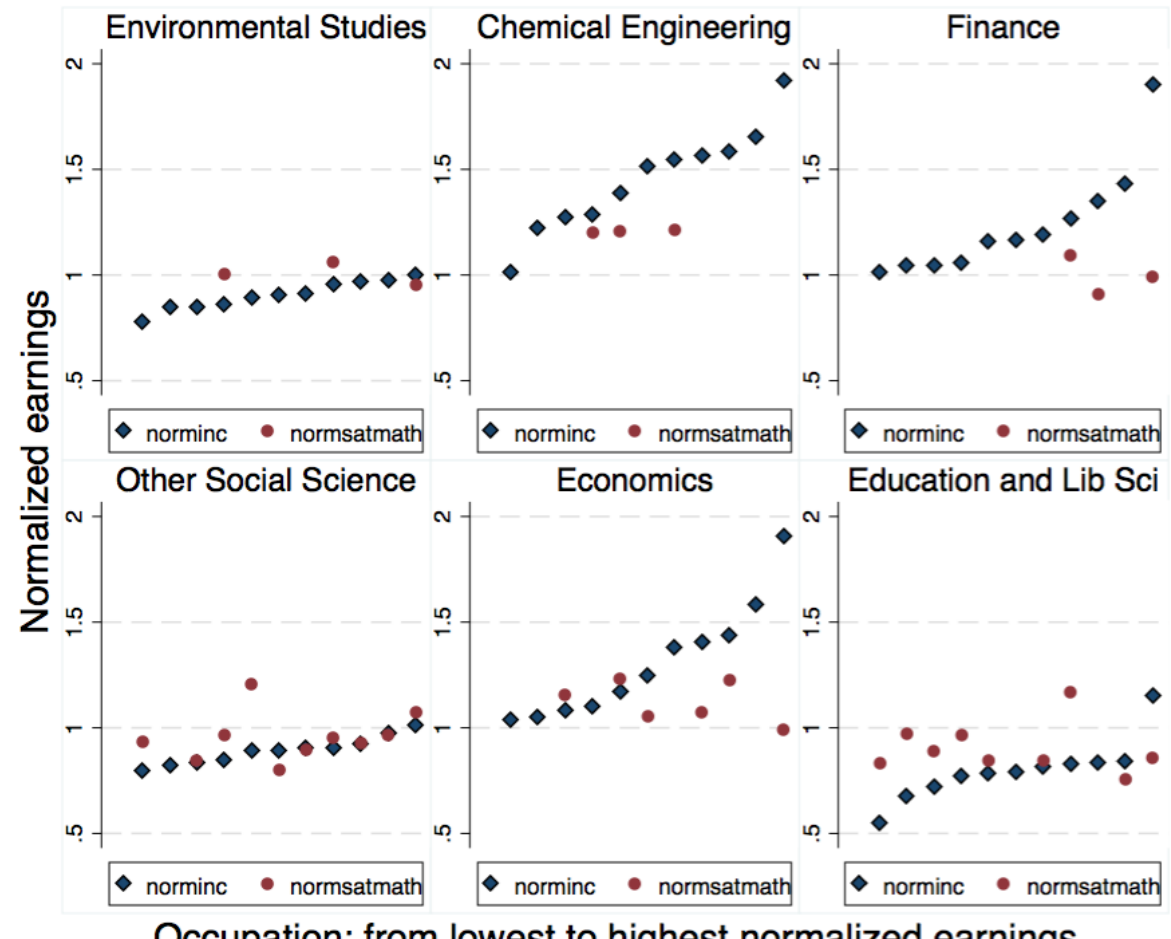

Occupation: from lowest to highest normalized earnings

Figure B.2 replicates our earnings regressions, excluding individuals who hold a graduate degree. While access to graduate degrees, which varies across majors, should be considered part of the returns to majors, this exercise allows us to investigate the extent to which the returns estimated in Section 5.3 are coming from graduate-degree holders.

Figures B.3 and B.4 replicate our results on the return to earnings using the Gini measure, but vary the set of majors that are compared. While our main results (see Figure 6) compare the top ten most specialized majors to the bottom ten (top and bottom quintiles), we show here that the same pattern holds when comparing the top and bottom five (deciles; Figure B.3) or top and bottom 17 (thirds; Figure B.4). 
Figure B.2: Earnings Return Excluding Graduate Degree Holders
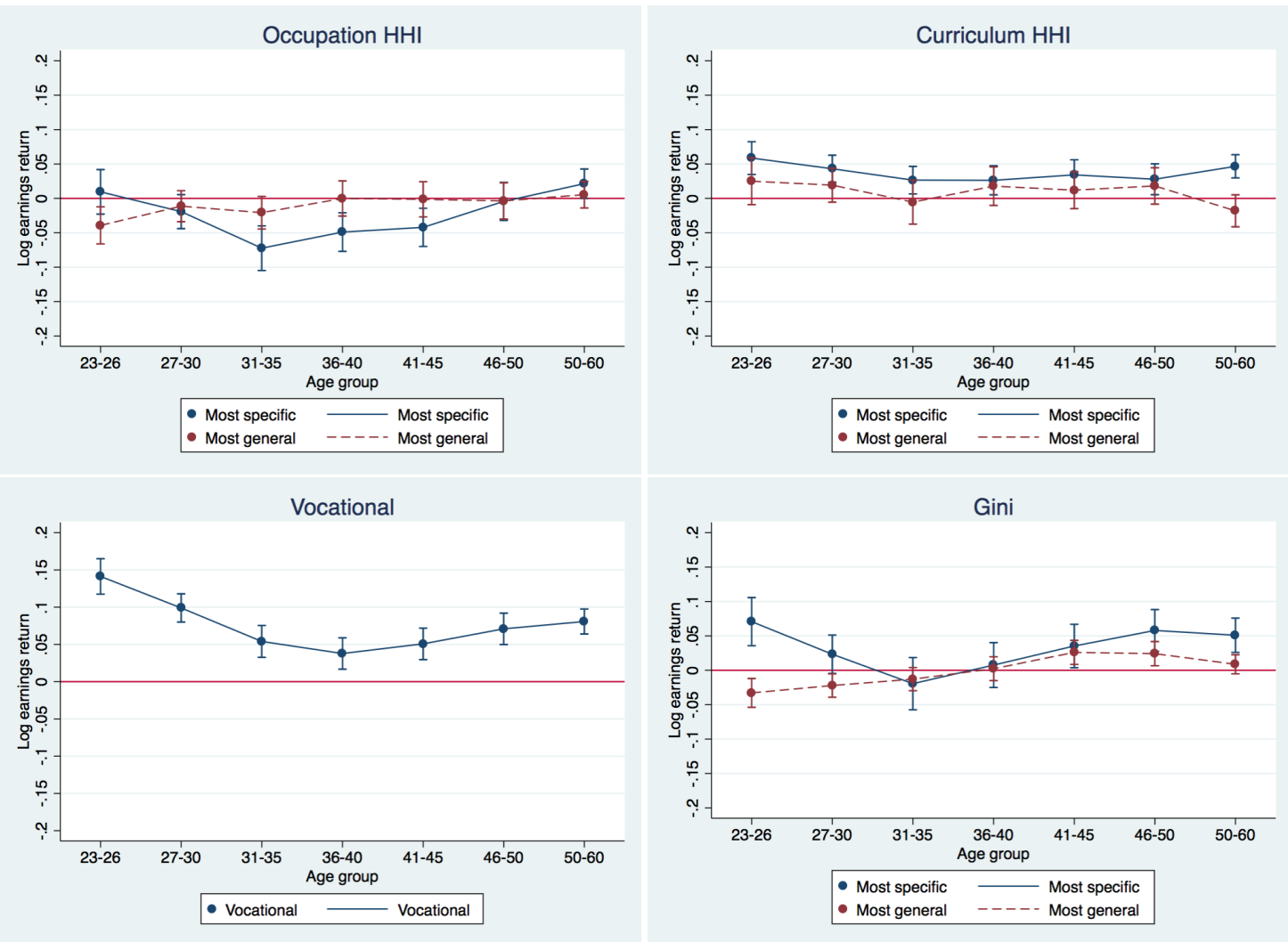

\section{B.1 Managers and Entrepreneurs}

Our measure of specific human capital is at the major level, rather than at the individual level. Our curriculum-based specificity measure therefore does not compare individuals of the same major with more or less concentrated course loads, but takes major-level averages of such measures. In Table B.1, we show correlations between our specificity measures and the indicators for entrepreneurship and managerial occupations. All three continuous measures show a negative correlation with managerial occupations, implying that graduates of more general majors are more likely to be employed as managers. For entrepreneurs, the Gini and occupation HHI measures show the same pattern, while the curriculum HHI shows a very slight positive correlation. Vocational majors are also less likely to become entrepreneurs. 
Figure B.3: Earnings Return: Gini Deciles Figure B.4: Earnings Return: Gini Thirds
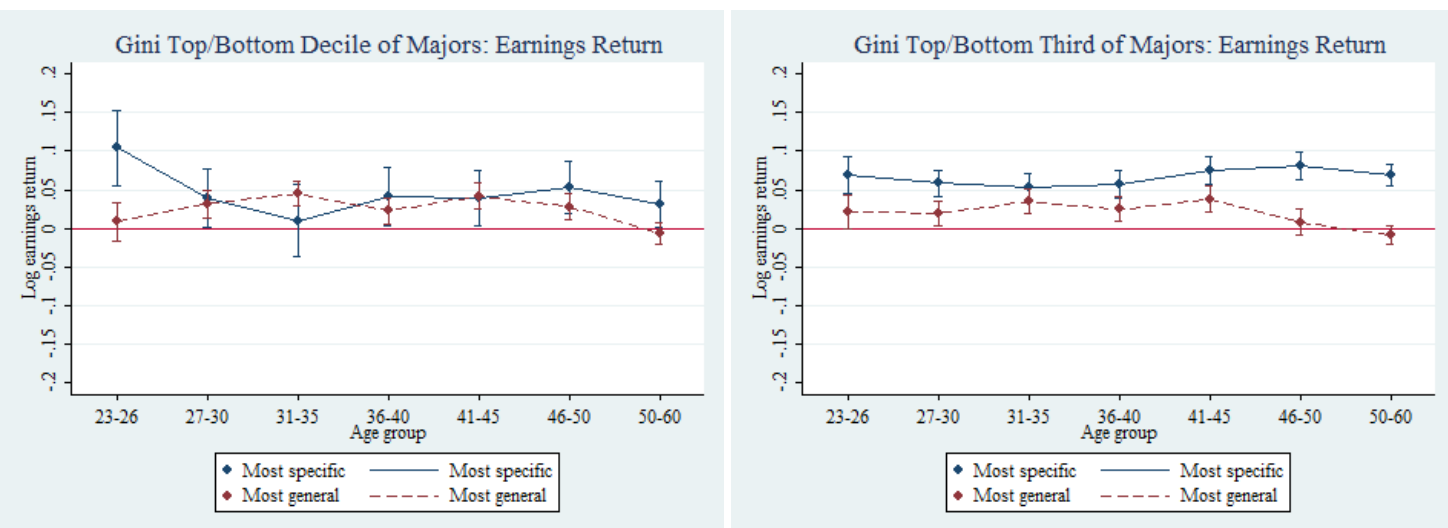

Table B.1: Correlation between specificity and entrepreneurship and managerial occupations and specificity

\begin{tabular}{l|llll} 
& Occ HHI & Curr HHI & Gini & Vocational \\
\hline Entrepreneur & -0.050 & 0.010 & -0.036 & -0.045 \\
Manager & -0.082 & -0.037 & -0.060 & 0.023
\end{tabular}

Figure B.5: Entrepreneurship and Specificity - All Measures
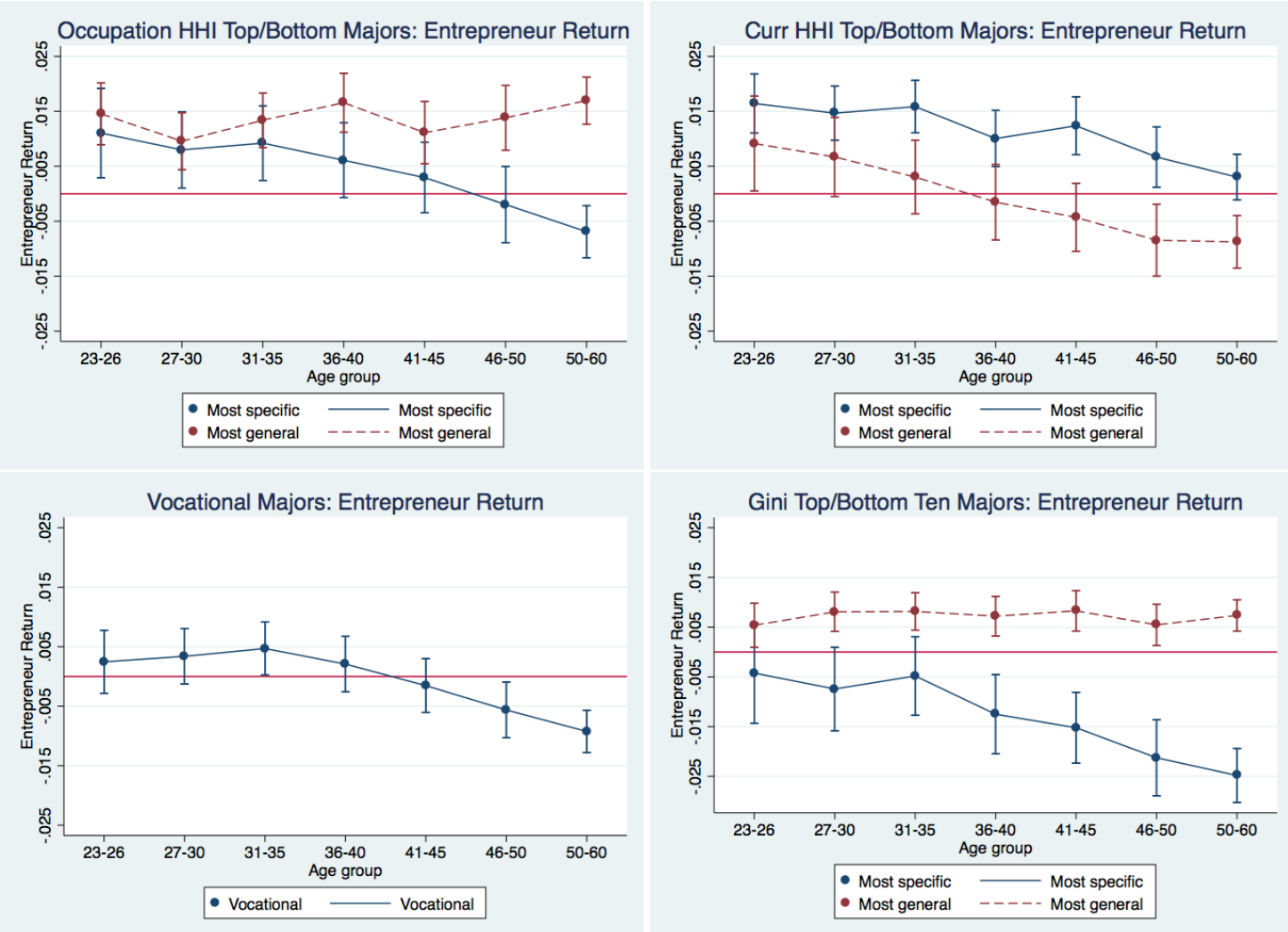
Figure B.6: Management and Specificity - All Measures
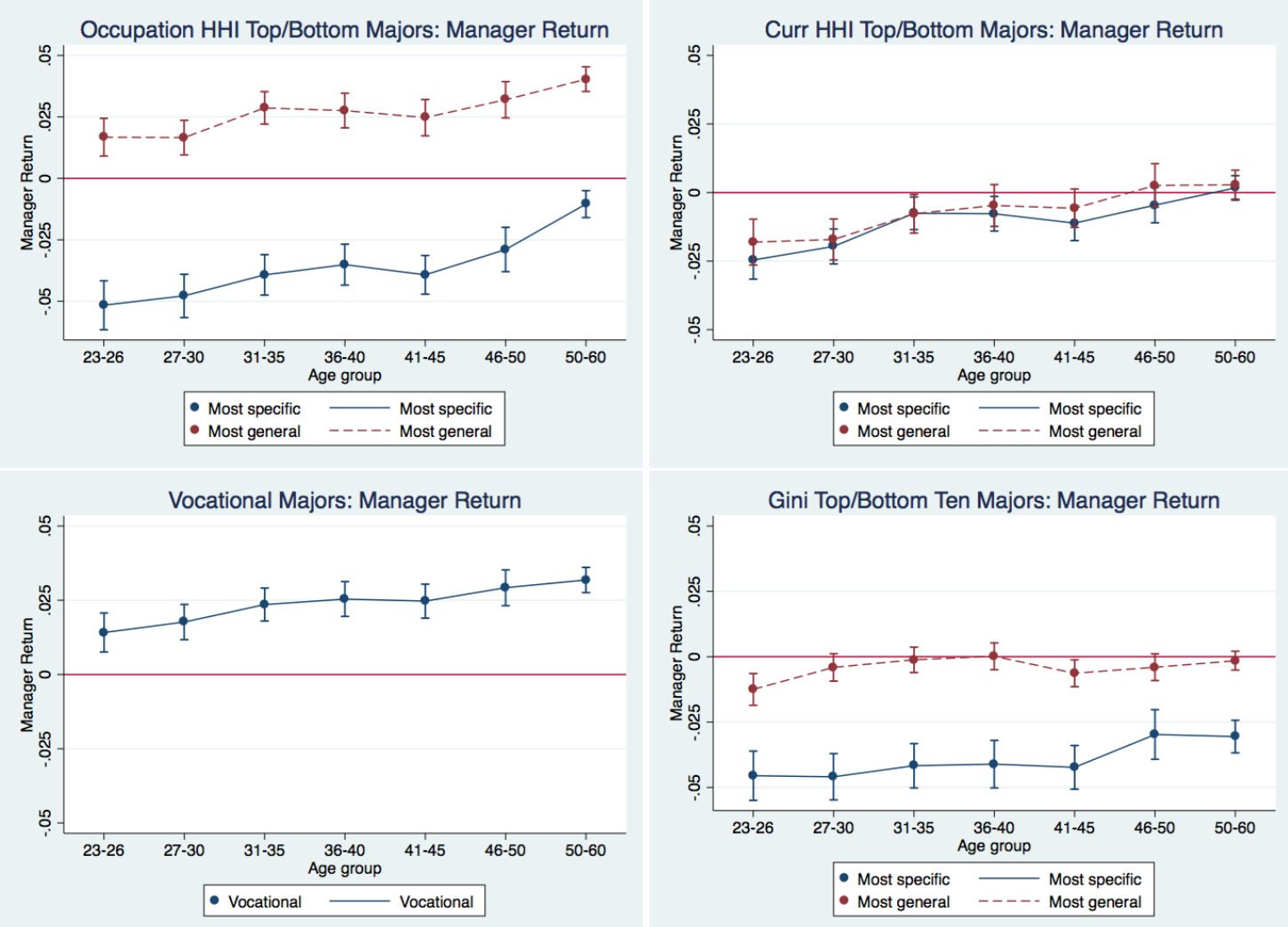
C Extended Results 
Table C.1: Hours

\begin{tabular}{|c|c|c|c|c|c|c|c|}
\hline & $\begin{array}{c}(1) \\
\text { lnhours }\end{array}$ & $\begin{array}{c}(2) \\
\text { lnhours }\end{array}$ & $\begin{array}{c}(3) \\
\text { lnhours }\end{array}$ & $\begin{array}{c}(4) \\
\text { lnhours }\end{array}$ & $\begin{array}{c}(5) \\
\text { lnhours }\end{array}$ & $\begin{array}{c}(6) \\
\text { lnhours }\end{array}$ & $\begin{array}{c}(7) \\
\text { lnhours }\end{array}$ \\
\hline Occ HHI & $\begin{array}{c}-0.008^{* * *} \\
(0.001)\end{array}$ & & & & & & \\
\hline Occ HHI* potexp & $0.001^{* * *}$ & & & & & & \\
\hline Occ $\mathrm{HHI}^{*}$ potexp2 & $\begin{array}{l}-0.000 \\
(0.000)\end{array}$ & & & & & & \\
\hline Occ HHI top decile & & $\begin{array}{c}-0.027^{* * *} \\
(0.004)\end{array}$ & & & & & \\
\hline Occ HHI top decile* potexp & & $\begin{array}{c}0.002^{* * * *} \\
(0.000)\end{array}$ & & & & & \\
\hline Occ HHI top decile*potexp2 & & $\begin{array}{c}-0.000^{* * *} \\
(0.000)\end{array}$ & & & & & \\
\hline Occ HHI bottom decile & & $\begin{array}{c}0.039^{* * *} * \\
(0.005)\end{array}$ & & & & & \\
\hline Occ HHI bottom decile*potexp & & $\begin{array}{c}-0.005^{* * *} \\
(0.001)\end{array}$ & & & & & \\
\hline Occ HHI bottom decile* potexp2 & & $\begin{array}{c}0.000^{* * *} \\
(0.000)\end{array}$ & & & & & \\
\hline Curr HHI & & & $\begin{array}{c}-0.007^{* * *} \\
(0.002)\end{array}$ & & & & \\
\hline Curr HHI* potexp & & & $\begin{array}{c}-0.001 * * * \\
(0.000)\end{array}$ & & & & \\
\hline Curr $\mathrm{HHI}^{*}$ potexp2 & & & $\begin{array}{c}0.000^{* * *} \\
(0.000)\end{array}$ & & & & \\
\hline Curr HHI top decile & & & & $\begin{array}{c}-0.016^{* * *} \\
(0.005)\end{array}$ & & & \\
\hline Curr HHI top decile*potexp & & & & $\begin{array}{c}-0.005^{* * *} \\
(0.001)\end{array}$ & & & \\
\hline Curr HHI top decile*potexp2 & & & & $\begin{array}{c}0.000^{* * *} \\
(0.000)\end{array}$ & & & \\
\hline Curr HHI bottom decile & & & & $\begin{array}{c}-0.045^{* * *} \\
(0.006)\end{array}$ & & & \\
\hline Curr HHI bottom decile*potexp & & & & $\begin{array}{c}0.005^{* * *} \\
(0.001)\end{array}$ & & & \\
\hline Curr HHI bottom decile*potexp2 & & & & $\begin{array}{c}-0.000 * * * \\
(0.000)\end{array}$ & & & \\
\hline Vocational & & & & & $\begin{array}{c}0.010^{* * *} * \\
(0.003)\end{array}$ & & \\
\hline Vocational*potexp & & & & & $\begin{array}{c}-0.001 * * * \\
(0.000)\end{array}$ & & \\
\hline Vocational* potexp2 & & & & & $\begin{array}{c}0.000^{* * *} \\
(0.000)\end{array}$ & & \\
\hline Theil & & & & & & $\begin{array}{c}-0.023^{* * *} \\
(0.001)\end{array}$ & \\
\hline Theil*potexp & & & & & & $\begin{array}{c}0.002^{* * *} * \\
(0.000)\end{array}$ & \\
\hline Theil* potexp2 & & & & & & $\begin{array}{c}-0.000 * * * \\
(0.000)\end{array}$ & \\
\hline Theil top decile & & & & & & & $\begin{array}{c}-0.051^{* * *} \\
(0.005)\end{array}$ \\
\hline Theil top decile*potexp & & & & & & & $\begin{array}{c}0.005^{* * *} \\
(0.001)\end{array}$ \\
\hline Theil top decile* potexp2 & & & & & & & $\begin{array}{c}-0.000^{* * *} \\
(0.000)\end{array}$ \\
\hline Theil bottom decile & & & & & & & $\begin{array}{l}-0.007 \\
(0.006)\end{array}$ \\
\hline Theil bottom decile*potexp & & & & & & & $\begin{array}{c}0.001 * * \\
(0.001)\end{array}$ \\
\hline Theil bottom decile* potexp2 & & & & & & & $\begin{array}{c}-0.000^{*} \\
(0.000)\end{array}$ \\
\hline Constant & $\begin{array}{c}6.880^{* * *} \\
(0.095)\end{array}$ & $\begin{array}{c}6.668^{* * * *} \\
(0.096)\end{array}$ & $\begin{array}{c}6.917^{* * *} \\
(0.076)\end{array}$ & $\begin{array}{c}7.243^{* * *} \\
(0.079)\end{array}$ & $\begin{array}{c}7.094^{* * *} \\
(0.091)\end{array}$ & $\begin{array}{c}6.431 * * * \\
(0.094)\end{array}$ & $\begin{array}{c}6.452^{* * *} \\
(0.093)\end{array}$ \\
\hline Observations & $2,469,329$ & $2,469,329$ & $2,469,329$ & $2,469,329$ & $2,469,329$ & $2,469,329$ & $2,469,329$ \\
\hline R-squared & 0.040 & 0.040 & 0.040 & 0.040 & 0.040 & 0.040 & 0.040 \\
\hline
\end{tabular}

All regressions also include gender, race, a quadratic in potential experience, graduation year dummies, year dummies, average SAT Math and Verbal scores in the major, and the standard deviation of SAT scores in the major. Data: ACS 2009-2015, college graduates aged 23 to 60. 
Table C.2: Employed

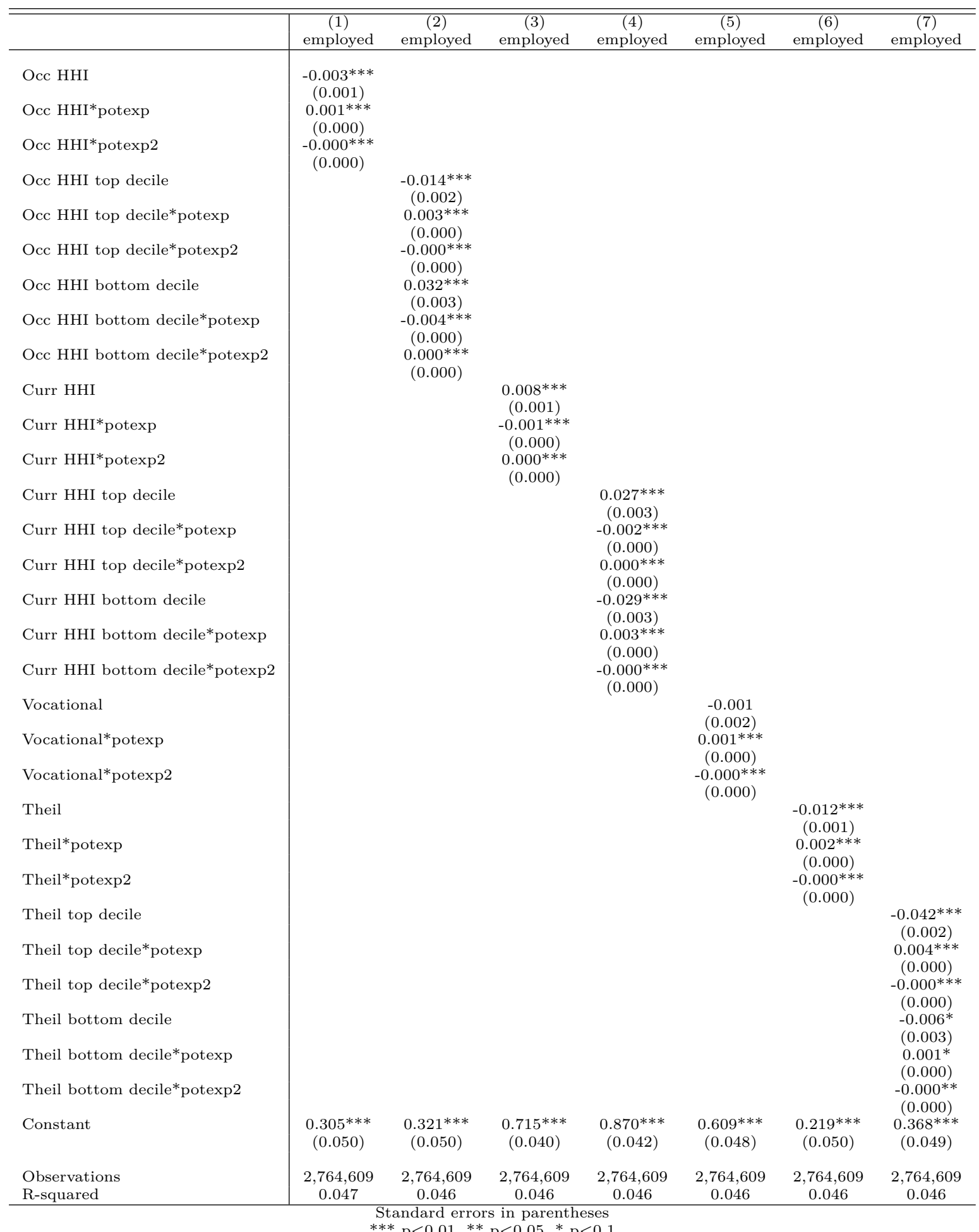

All regressions also include gender, race, a quadratic in potential experience, graduation year dummies, year dummies, average SAT Math and Verbal scores in the major, and the standard deviation of SAT scores in the major. Data: ACS 2009-2015, college graduates aged 23 to 60. 
Table C.3: Full-time

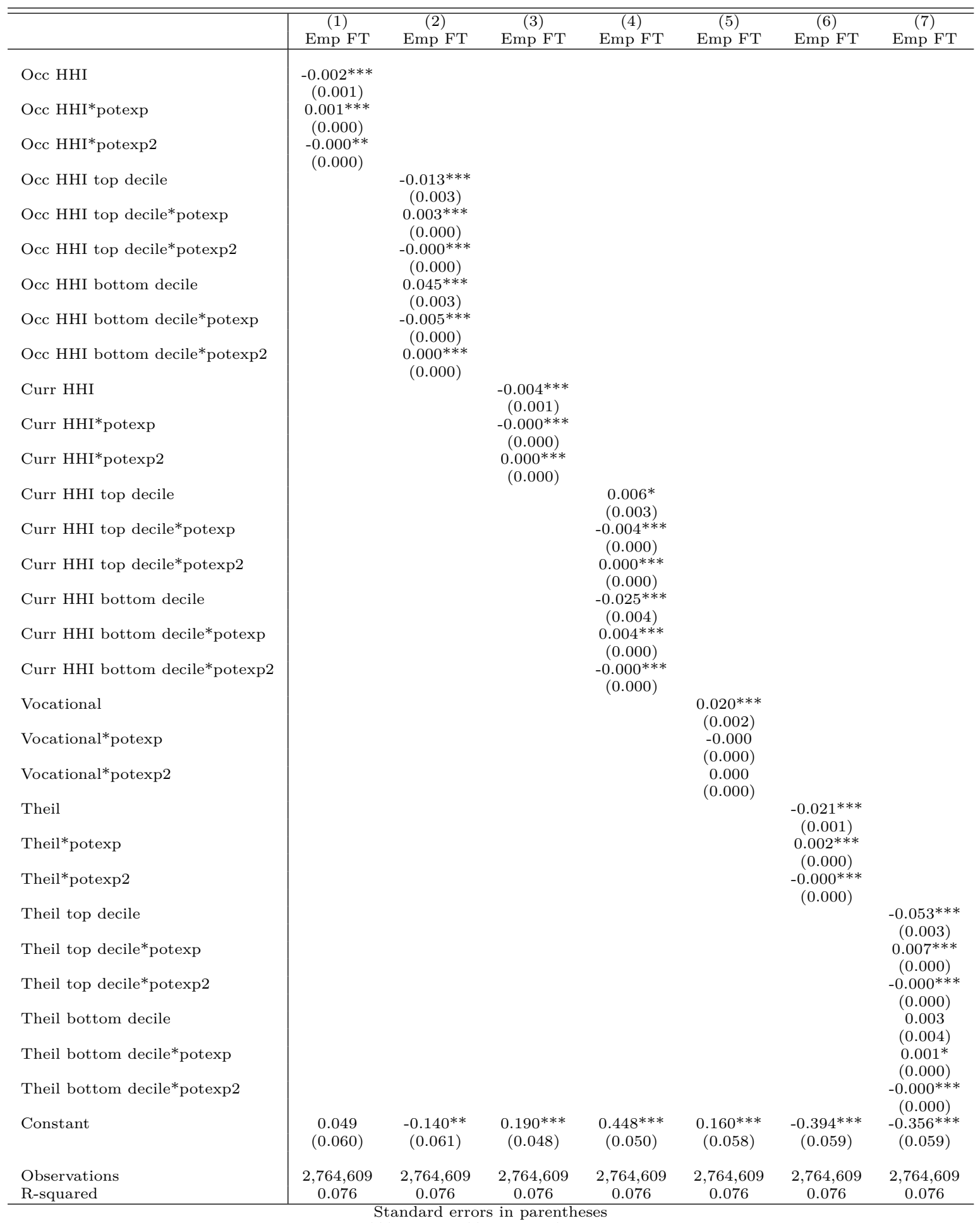
Standard errors in parentheses

All regressions also include gender, race, a quadratic in potential experience, graduation year dummies, year dummies, average SAT Math and Verbal scores in the major, and the standard deviation of SAT scores in the major. Data: ACS 2009-2015, college graduates aged 23 to 60. 